\title{
Species turnover between the northern and southern part of the South China Sea in the Elaphropeza Macquart mangrove fly communities of Hong Kong and Singapore (Insecta: Diptera: Hybotidae)
}

\author{
Patrick GROOTAERT \\ Royal Belgian Institute of Natural Sciences, Brussels, Belgium and National Biodiversity Centre, \\ National Parks, Singapore; Lee Kong Chian Natural History Museum, \\ National University of Singapore, Singapore. \\ Email: pgrootaert@yahoo.co.uk \\ urn:1sid:zoobank.org:author:B80BC556-9087-4D0D-9D69-7FA9BE5779C4
}

\begin{abstract}
A recent survey of the mangroves around Hong Kong revealed the presence of seven species of the genus Elaphropeza Macquart, 1827. All belong to a group of yellow species that occur exclusively in mangroves. Three species were previously known: Elaphropeza calcarifera Bezzi, 1912 and E. xanthocephala Bezzi, 1912, both from Taiwan, and E. riatanae Shamshev \& Grootaert, 2007 from Singapore. Four species are new to science: Elaphropeza furcatella sp. nov., E. guenardi sp. nov., E. hongkongensis sp. nov. and E. hongshulin sp. nov. All seven species are described or an extended diagnosis is provided. All species are figured and NGS barcodes are made available. A key is given for the Hong Kong species and their siblings from Singapore and Taiwan. Remarkable is that five of the seven species are more or less closely related to species occurring in Singapore. Genetic distances and morphologic differences are congruent. The species turnover between the northern part and the southern part of the South China Sea is high, with only one of the seven species present in both regions.
\end{abstract}

Keywords. Mangrove, Elaphropeza, species turnover.

Grootaert P. 2019. Species turnover between the northern and southern part of the South China Sea in the Elaphropeza Macquart mangrove fly communities of Hong Kong and Singapore (Insecta: Diptera: Hybotidae). European Journal of Taxonomy 554: 1-27. https://doi.org/10.5852/ejt.2019.554

\section{Introduction}

As was shown in a long-term survey of the mangrove fauna of Singapore (Grootaert \& Shamshev 2012), the hybotid flies, and especially the species of Elaphropeza Macquart, 1827, are very diverse in mangroves. Here, the relationship is examined between the fauna recorded in Singapore situated in the southern part of the South China Sea and Hong Kong situated at about $3000 \mathrm{~km}$ north in the northern part of the South China Sea. Do the same species or species groups occur over the South China Sea mangroves and what is the species turnover? 
Singapore is situated near the equator at $1^{\circ} \mathrm{N}$ and has a humid tropical climate. There are two monsoonal periods with rains from March to June, dryer in July and August, resuming rain from September onward and sometimes very humid in January followed by very little or no rain in February (Meteorological Service Singapore 2019). Being an island on the equator, the average temperature is the same throughout the year with $32^{\circ} \mathrm{C}$ during the day and $24^{\circ} \mathrm{C}$ at night. The mangrove flora is diverse with nineteen species of true mangrove trees (Yang et al. 2011; Ng \& Sivasothi 1999).

Hong Kong is situated at $22^{\circ} \mathrm{N}$ and thus at a much higher northern latitude. It has a seasonal subtropical climate and the seasons are more marked with a 'winter and a summer period'. Climate and weather information are available from the Hong Kong Observatory (2017). Mangroves reach their northern distribution limit in Hong Kong and they are composed of only eight mangrove tree species, among them Bruguiera gymnorhiza or large-leafed orange mangrove is fairly common.

Elaphropeza is a genus of small leaf-dwelling predatory flies that thrives in the tropics. It is distributed worldwide with about 220 known species (Yang et al. 2007; Shamshev \& Grootaert 2007; Grootaert \& Shamshev 2012). The species from the Chinese mainland were reviewed by Yang \& Gaimari (2005) who also provided a key. The Oriental species were revised by Shamshev \& Grootaert (2007) and Grootaert \& Shamshev (2012, 2015). Yang et al. (2006) revised species of Elaphropeza from neighbouring Guangdong Province in China, where they found three species: Elaphropeza chebalingensis Yang, Merz \& Grootaert, 2006, E. guiensis (Yang \& Yang, 1989) and E. plumata Yang, Merz \& Grootaert, 2006. Recently, the fauna of Taiwan was revised by Wang et al. (2012), where they recorded fourteen species with a key to the species of Taiwan.

All Hong Kong species were NGS-barcoded (313 bp) following the technique described in Meier et al. (2016), so that cryptic species became visible and females, which are usually very difficult to identify based on morphological characters, could be linked to the corresponding males. Specimens of Elaphropeza riatanae Shamshev \& Grootaert, 2007 showed a high variation in the colouration of the scutellum, which is a key character to identify species of Elaphropeza. The barcodes did not support this variation, indicating that all specimens were conspecific.

\section{Material and methods}

A survey was made in autumn 2017 with Malaise traps at 22 mangrove sites all around Hong Kong (C.Taylor, U. Chang and B. Guénard) (Fig. 1). The traps were operational during 2 weeks per site. Most of the stations were back mangroves and only a few front mangroves. Each station received a code, e.g., 5BM1 in which 5B refers to the station and M1 to the first period that the trap was operated at that station.

All specimens were conserved in 70\% ethanol. Holotypes and paratypes are conserved in the collections of the Royal Belgian Institute of Natural Sciences in Brussels (RBINS). Voucher specimens are deposited in the Natural History Museum of the University of Hong Kong (HKU) and the Lee Kong Chian Natural History Museum in Singapore (LKCNH).

The Hong Kong specimens were NGS-barcoded (313 bp) at the National University of Singapore following the techniques described in Meier et al. (2016) and Wang et al. (2018) in a cost effective and non-destructive way (Wong et al. 2014) allowing females to be matched with males (Yeo et al. 2018) Their reference code starts with HKC followed by a number. A few specimens were handled by Ms Jayanthi Puniamoorthy using the classic technique $(630 \mathrm{bp})$ and their reference code starts with JP. 
The Singapore species were barcoded at RBINS in Brussels as described in Nagy et al. (2013). Their reference code starts with $\mathrm{AB}$ followed by a number. These barcodes are available from GenBank.

Estimates of Evolutionary Divergence between sequences were conducted in MEGA7 (Kumar et al. 2016; Tamura et al. 2004). The number of base substitutions per site between sequences are shown. Analyses were conducted using the Maximum Composite Likelihood model. The analysis involved 78 nucleotide sequences. Codon positions included were $1 \mathrm{st}+2 \mathrm{nd}+3 \mathrm{rd}+$ Noncoding. All positions containing gaps and missing data were eliminated. There was a total of 295 positions in the final dataset.

The stacked habitus images were made according to Brecko et al. (2014). The morphology and terminology of Elaphropeza are described in Grootaert \& Shamshev (2012). The male terminalia were removed, macerated, prepared on a microscopic slide in a gel so that the terminalia could be orientated in the same position and drawn with a camera lucida.

Abbreviations used are as follows:

$\mathrm{c}=$ cercus (fused right and left cercus)

$\mathrm{e}=$ epiproct

lc $=$ left cercus

lel $=$ left epandrial lamella

$1 \mathrm{~s}=$ left surstylus

$\mathrm{rc}=$ right cercus

rel $=$ right epandrial lamella

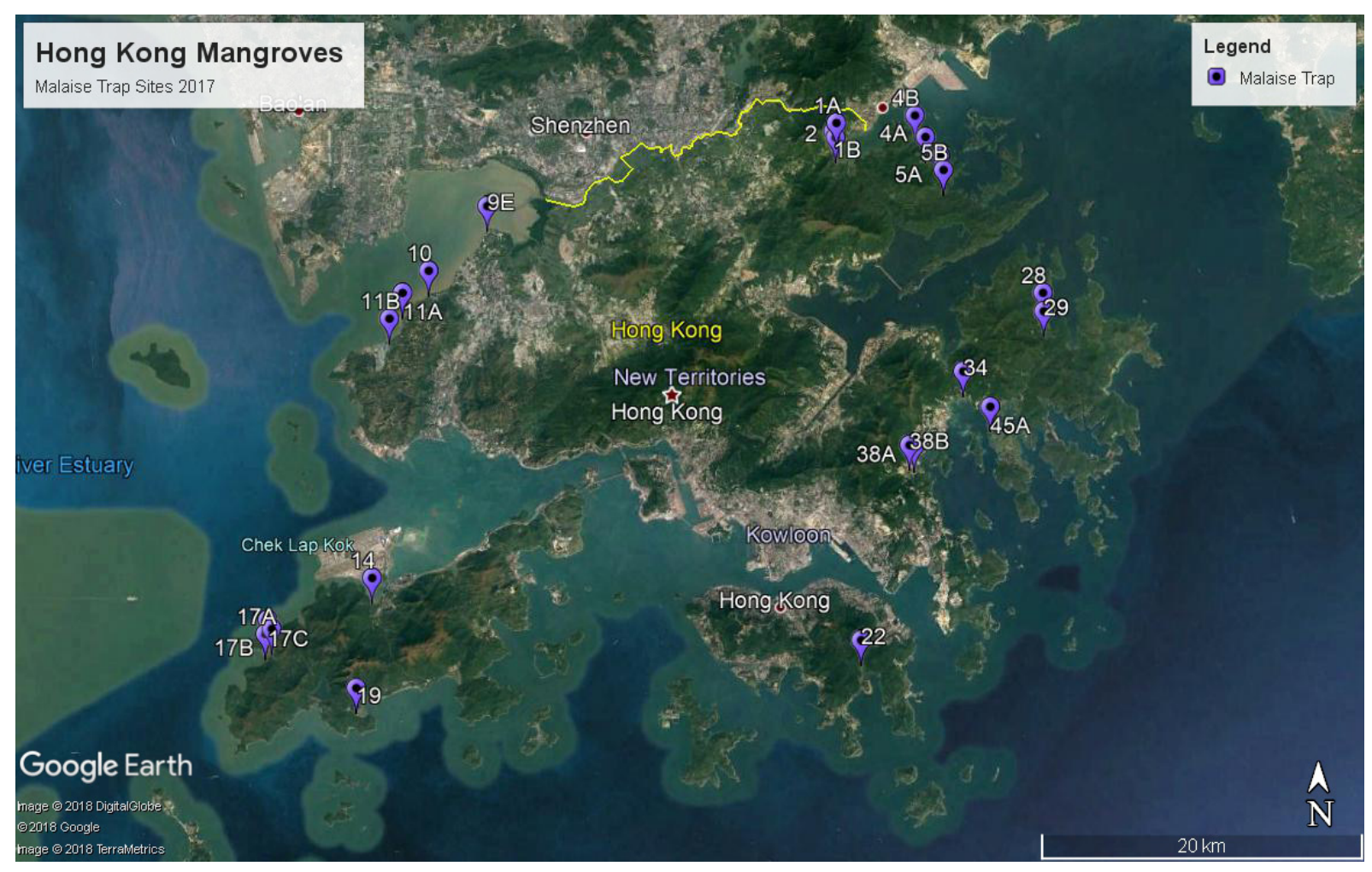

Fig. 1. Distribution of the Malaise traps around Hong Kong (map by C. Taylor and U. Chang). 


\title{
Results
}

\author{
Class Insecta Linnaeus, 1758 \\ Order Diptera Linnaeus, 1758 \\ Superfamily Empidoidea Latreille, 1804 \\ Family Hybotidae Macquart, 1823 \\ Subfamily Tachydromiinae Meigen, 1822 \\ Genus Elaphropeza Macquart, 1827
}

Elaphropeza Macquart, 1827: 86 (type-species: Tachydromia ephippiata Fallén, 1815, by monotypy).

Ctenodrapetis Bezzi, 1904: 351 (as subgenus of Drapetis) (type-species: Drapetis (Ctenodrapetis) ciliatocosta Bezzi, 1904 by subsequent designation in Melander 1928: 309).

The genus Elaphropeza can be distinguished from other genera of the Drapetidini by the following combination of characters: occiput convex, antennae not upturned, postpedicel conical, its ventral margin as straight as dorsal margin, stylus apical, anepisternum bare, wing with shortened cell br, abdominal tergites may bear squamiform setae, intersegmental modifications present between tergites 3-5 or 4-5. For a detailed diagnosis and the general morphology we refer to Grootaert \& Shamshev (2012).

\section{Key to male Elaphropeza from mangroves in Hong Kong}

The present key is limited to the species occurring in mangroves in Hong Kong and their siblings in Singapore and Taiwan, modified after Grootaert \& Shamshev (2012). All species belong to the E. ephippiata group in having the proepisternum bare just above the fore coxa (lacking a long upturned bristle) and the abdominal tergite 3 with unmodified setae, lacking squamiform setae.

All species here are yellow with an entirely yellow scutum without spots, with yellow or black occiput and hind tibia with a single anterodorsal bristle near the middle. Wings hyaline or uniformly infuscate.

For black species or those with hind tibia without prominent bristles or with an apical curved spine, or scutum with a colour pattern or wing with a pattern, check Grootaert \& Shamshev $(2012,2015)$ for Oriental species or Yang et al. $(2005,2006)$ for China and Wang et al. (2012) for Taiwan.

1. Occiput black 2

- Occiput yellow (Taiwan, Hong Kong).

E. xanthocephala Bezzi, 1912

2. Hind tibia with long pointed apical projection. Scutellum and metanotum brown. Acrostichal bristles lacking on prescutellar depression. Haltere yellow (Taiwan, Hong Kong)

- Hind tibia with short, rounded apical projection. Different combination of characters .................... 3

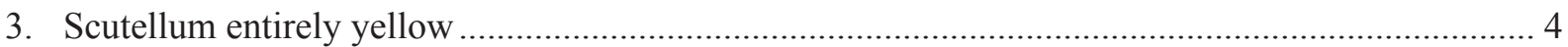

- Scutellum largely brown or black (in E. riatanae there is a variation of colouration from entirely yellow to entirely brown to black scutellum, but metanotum is always black)............................. 10

4. Acrostichal bristles extending to base of scutellum. Haltere darkened ........................................... 5

- Acrostichal bristles lacking on prescutellar depression. Haltere yellow ............................................ 6

5. Postpedicel about $6.0 \times$ longer than wide, stylus about $0.7 \times$ length of postpedicel. Right epandrial lamella with only two pale blunt spines. Tip of fused part of cerci long, with short bristles. Metanotum reddish-yellow (Singapore)

E. asiophila Shamshev \& Grootaert, 2007 
- Postpedicel about $4.6 \times$ as long as wide, stylus nearly as long as postpedicel $(0.86 \times)$. Tip of right epandrial lamella with 3 black blunt spines; fused part of fused cerci shorter, with long bristles (Fig. 7A-B). Metanotum rather orange-yellow (Hong Kong) E. guenardi sp. nov.

6. Fore tibia and tarsus, mid and hind tarsomere 5 brownish (legs sometimes entirely yellow in E. furcatella sp. nov). Abdominal tergite 4 and 5 with or without squamiform setae.....

- Legs with only tarsomere 5 brown. Abdominal tergite 4 with slightly flattened setae, tergite 5 with squamiform setae

7. Abdominal tergites 4 and 5 with squamiform setae. Male: cerci broadly fused, forked, right epandrial lamella truncate apically, lacking spines (Singapore).....

E. furca Shamshev \& Grootaert, 2007

- Abdominal tergites 4 and 5 without squamiform setae. Male: tip of right epandrial lamella forked (Fig. 5A), tip of cercus truncate, but pointed at the left side (Fig. 5B). Legs entirely yellow, sometimes fore and mid tibiae and tarsi dusky yellow, not brown.

E. furcatella sp. nov.

8. Male: right epandrial lamella with unmodified setation, lacking spines (Fig. 11F) (Singapore) ........ E. lowi Grootaert \& Shamshev, 2012

- Male: right epandrial lamella with three apical black spines or a single subapical spine at the inside.

9. Tip of right epandrial lamella broadened, with three black spines apically (Fig. 11E) (Malaysia, Singapore)

E. malayensis Shamshev \& Grootaert, 2007

- Tip of right epandrial lamella not broadened and bearing a single spinule at the inside (Fig. 11B)

E. hongshulin sp. nov.

10. Scutellum brown medially (Taiwan).

E. marginalis Bezzi, 1912

- Scutellum entirely brown or black.

11. Legs with fore tibia and tarsus wholly brown, hind femur near apex above brownish (Singapore, Hong Kong)....

E. riatanae Shamshev \& Grootaert, 2007

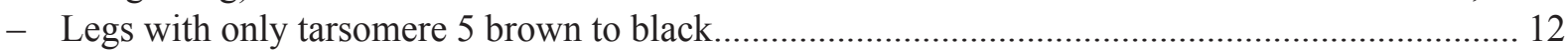

12. Acrostichal bristles biserial near middle of scutum, lacking on prescutellar depression 13

- Acrostichal and dorsocentral bristles multiserial.

13. Larger (about $2.5 \mathrm{~mm}$ ). Left surstylus with a shallow notch apically (Grootaert \& Shamshev 2012: fig. 155) (Singapore).

E. feminata Shamshev \& Grootaert, 2007

- Large (about 1.7 to $2.3 \mathrm{~mm}$ ). Left surstylus with a deep notch on dorsal border (Fig. 9C) (Hong Kong)

E. hongkongensis sp. nov.

14. Hind tibia with long, pointed apical projection; two long prescutellars (Taiwan, Hong Kong)

E. calcarifera Bezzi, 1907

- Hind tibia with small, rounded apical projection; one long prescutellar bristle (Taiwan).

E. melanura Bezzi, 1912

Elaphropeza calcarifera Bezzi, 1907

Figs 2-3

Elaphropeza calcarifera Bezzi, 1907: 488, male, type locality: Taiwan, Takao.

Elaphropeza calcarifera - Bezzi 1912: 489, female. — Shamshev \& Grootaert 2007: 114, figs 188-190, re-description; neotype designated from Taiwan, Anping. 


\section{Material examined}

HONG KONG • 1 ð , 4 우; Shui Hau (19M1); $22.21936^{\circ} \mathrm{N}, 113.91898^{\circ} \mathrm{E}$; C. Taylor and U. Chang leg.; 1-14 Nov. 2017; male dissected and figured (Fig. 3); RBINS • 2 के $0^{\text {; }}$ Sam A Chung (5BM1); $22.50829^{\circ} \mathrm{N}, 114.27248^{\circ} \mathrm{E}$; C. Taylor and U. Chang leg.; 11-27 Dec. 2017; both dissected and barcoded with references: JP2B, JP2C; both have yellow tergites 6 and 7; RBINS $\bullet 5$ $\delta^{\lambda}, 1$ क; Tai Tam (22M1); $22.24614^{\circ} \mathrm{N}, 114.22334^{\circ} \mathrm{E}$; C. Taylor and U. Chang leg.; 9-23 Oct. 2017; with following NGS barcode references: HKC_0000787 † 22M1, HKC_0000788 ð̊ 22M1, HKC_0000789 ð 22M1,

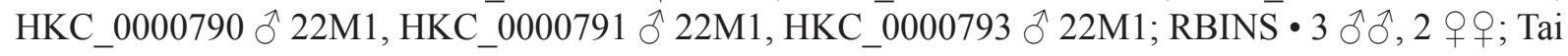
Tam (22M2); $22.24614^{\circ} \mathrm{N}, 114.22334^{\circ} \mathrm{E}$; C. Taylor and U. Chang leg.; $23-30$ Oct. 2017; with following NGS barcode references: HKC_0000798 ô 22M2, HKC_0000800 §̊ 22M2, HKC_0000804 ㅇ 22M2, HKC_0000808 ð̊ 22M2, HKC_0000809 ㅇ 22M2; RBINS.

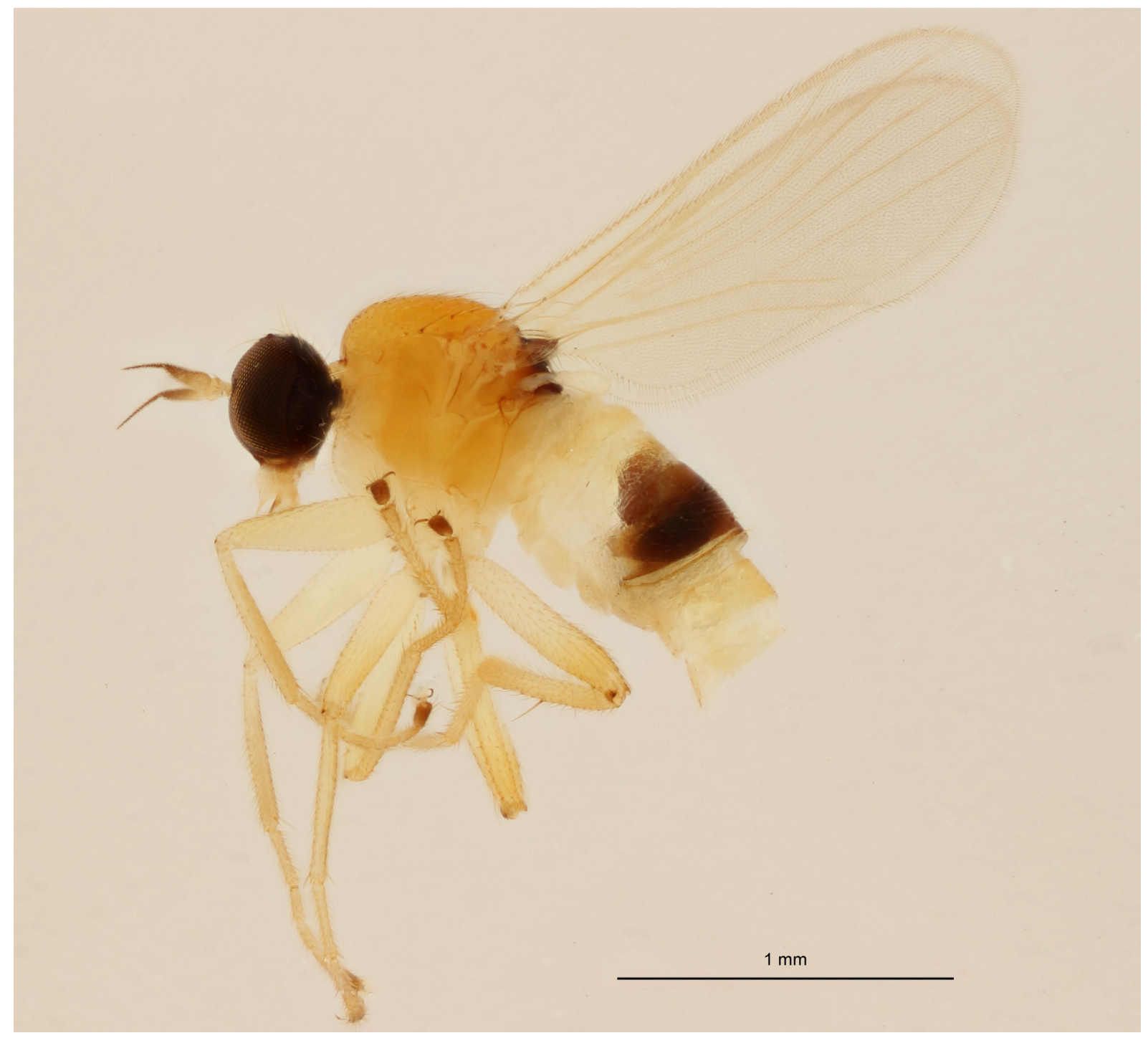

Fig. 2. Elaphropeza calcarifera Bezzi, 1907, đ̃, habitus, RBINS (leg. C. Taylor and U. Chang; photo A. Samoh). 


\section{Description}

\section{Male (Fig. 2)}

Body. $1.5-1.7 \mathrm{~mm}$ long; wing $1.3-1.4 \mathrm{~mm}$ long.

HEAD. Scape and pedicel yellow, postpedicel brownish, base largely yellow. Inner vertical bristles nearly twice as long as outer verticals. Postpedicel $3 \times$ as long as wide; stylus as long as postpedicel.

THORAX. Scutum yellow, scutellum and metanotum brown. Acrostichals irregularly tri- to quadri-serial, not reaching border of scutellum. Two longer prescutellars, distinct from other short dorsocentrals. Most apical one twice as long as the preceding one.

Legs. Yellow, but tarsomere 5 of all legs contrastingly black. Mid femur ventrally with a single row of short spine-like bristles, not as long as femur is wide, bristles brown in basal half while pale in apical half. Mid tibia with short somewhat flattened bristles, not really spinules ending in indistinct pale short apical spine. A long pale preapical posterior bristle present. Hind tibia with long brown anterodorsal seta near middle.

WING. Clear, veins yellow; costal bristle yellow. Haltere white.

AвDOMEN. Tergites 1-3 yellow, tergite 4 large, shining black, lacking squamiform setae, tergite 5 very narrow, with a row of squamiform setae; tergites 6-7 yellow.

Terminalia (Fig. 3). Right epandrial lamella black, except for dusky yellow base. Cerci fused with pale brown digitiform tip, a strong bristle below middle (Fig. 3B). Left surstylus black, narrow with a truncate tip bearing yellow hairs, dorsal margin with a very long seta at base and a few strong setae near middle (Fig. 3C).
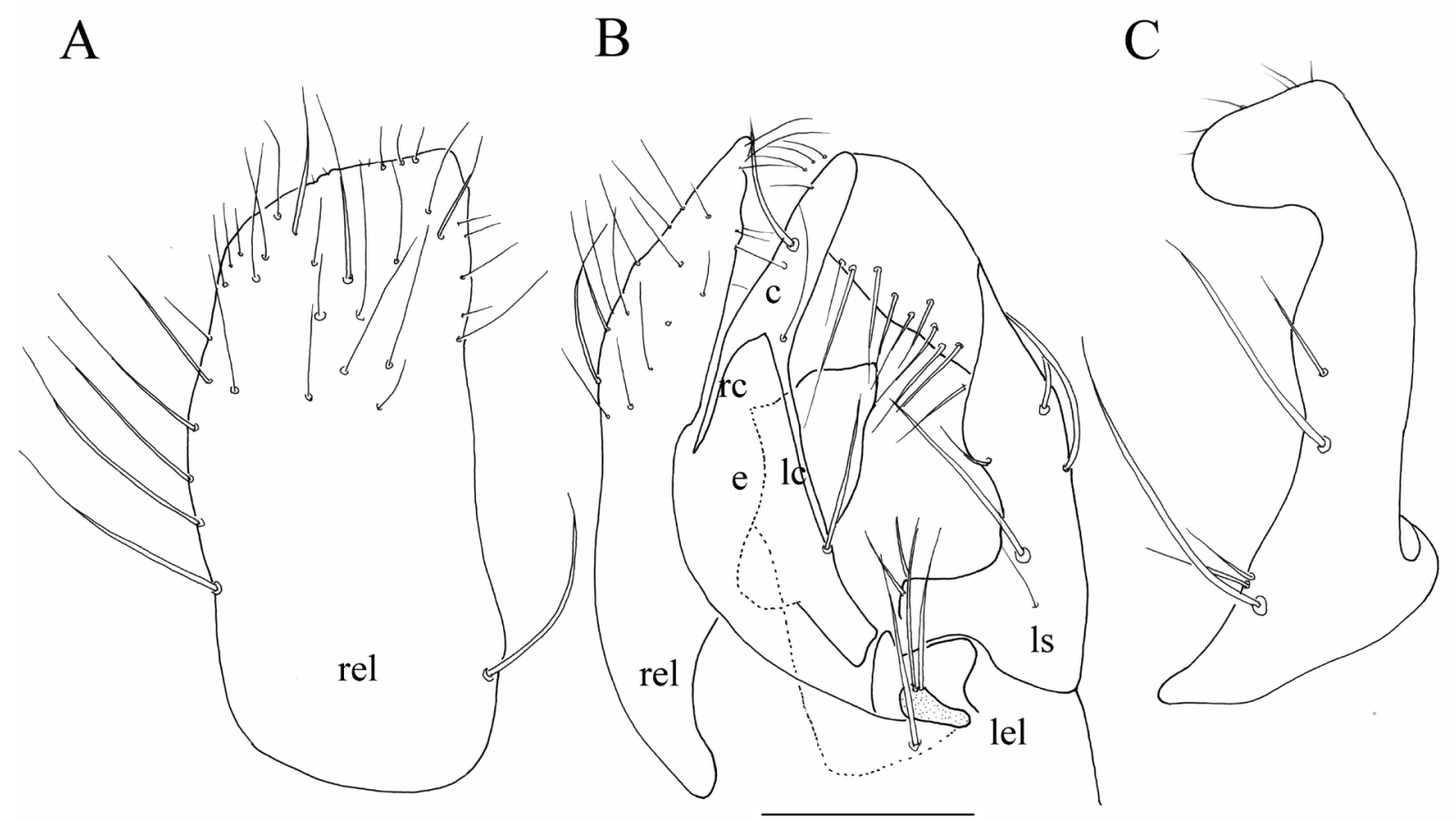

Fig. 3. Elaphropeza calcarifera Bezzi, 1907, male terminalia, RBINS (leg. C. Taylor and U. Chang). A. Right epandrial lamella. B. Epandrium, dorsal view. C. Left surstylus. Scale bar: $0.1 \mathrm{~mm}$. 


\section{Female}

Body. 1.7 - $1.8 \mathrm{~mm}$ long; wing $1.4 \mathrm{~mm}$ long.

Identical to male in most respects. Stylus a little longer than postpedicel. Tergite 8 black, cerci very short, pale brown, tergite 8 long, brown, produced beyond the cerci. The ovipositor is quite large and on superficial look like male terminalia.

\section{Remarks}

The presence of a pointed apical projection in E. calcarifera on the hind tibia is easily overlooked and, therefore, this species is mentioned twice in the key above. When the pointed projection is overlooked, it will lead in the key to the Oriental Elaphropeza (see Grootaert \& Shamshev 2012) E. melanura Bezzi, 1912, also described from Taiwan. Unfortunately, the neotype male of $E$. melanura has not been dissected to illustrate the male terminalia. Apart from the pointed projections, the differences with E. calcarifera are small, but there are a few characters to distinguish the two species. In E. melanura the inner verticals are long, while the outer ones are hardly prominent. In E. calcarifera the inner verticals are also very long and the outer ones distinct and more than half as long as the inner ones.

In E. melanuroides Grootaert \& Shamshev, 2015, another related species, the inner verticals are as long as the outer verticals. The postpedicel is brown in E. melanura, while in both E. calcarifera and $E$. melanuroides the postpedicel is brown with its base ventrally largely yellow. There is one long prescutellar bristle in E. melanura, while E. calcarifera and E. melanuroides have two longer prescutellars. The haltere is yellow in E. melanura while white in E. melanuroides. However, the colour of the haltere might have become yellow over time as it is a dried specimen. Both E. calcarifera and E. melanuroides were fresh in our study and have been studied in ethanol. The mid femur in E. melanura bears two rows of spine-like, short ventral bristles. In E. calcarifera there is only a single row of strong bristles. In E. melanuroides the mid femur has bristles that are not spine-like; however, on the apical third there are some darker bristles.

In E. calcarifera there is variation in the colour of tergites 6 and 7 from very pale to yellow and even dusky yellow.

Elaphropeza furcatella sp. nov. urn:1sid:zoobank.org:act:8DC272D2-7B30-4371-A22F-C437B77BBAA9

Figs $4-5$

\section{Etymology}

The specific name is from the Latin 'furca, furcatella', meaning 'fork, small fork', and alludes to the fork-shaped tip of the right epandrial lamella.

\section{Material examined}

Holotype

HONG KONG • O' ; Tai Tan (28M1); $22.43857^{\circ} \mathrm{N}, 114.33327^{\circ}$ E; C. Taylor and U. Chang leg.; 5-19 Dec. 2017; barcode reference JP1F (not dissected); RBINS.

\section{Paratypes}

HONG KONG • 1 \&; same collection data as for holotype; barcode reference HKC_0000505; RBINS • 1 §̊; Tai Tam (22M2); $22.24614^{\circ} \mathrm{N}, 114.22334^{\circ} \mathrm{E}$; C. Taylor and U. Chang leg.; 9-23 Oct. 2017; barcode reference HKC_0000801; RBINS. 


\section{Description}

\section{Male (Fig. 4)}

BoDy. $1.4 \mathrm{~mm}$ long; wing $1.5 \mathrm{~mm}$ long.

HEAD. Occiput black, scape and pedicel yellow, postpedicel brown, but paler on basal half. Postpedicel nearly $4 \times$ as long as wide. Stylus a little longer than postpedicel. Palpus yellow, with white basal and pale brown subapical bristle. Proboscis pale yellowish.

THORAX. Yellow, including scutellum, metanotum dusky yellow (not brown). Acrostichals quadri-serial, not reaching scutellum.

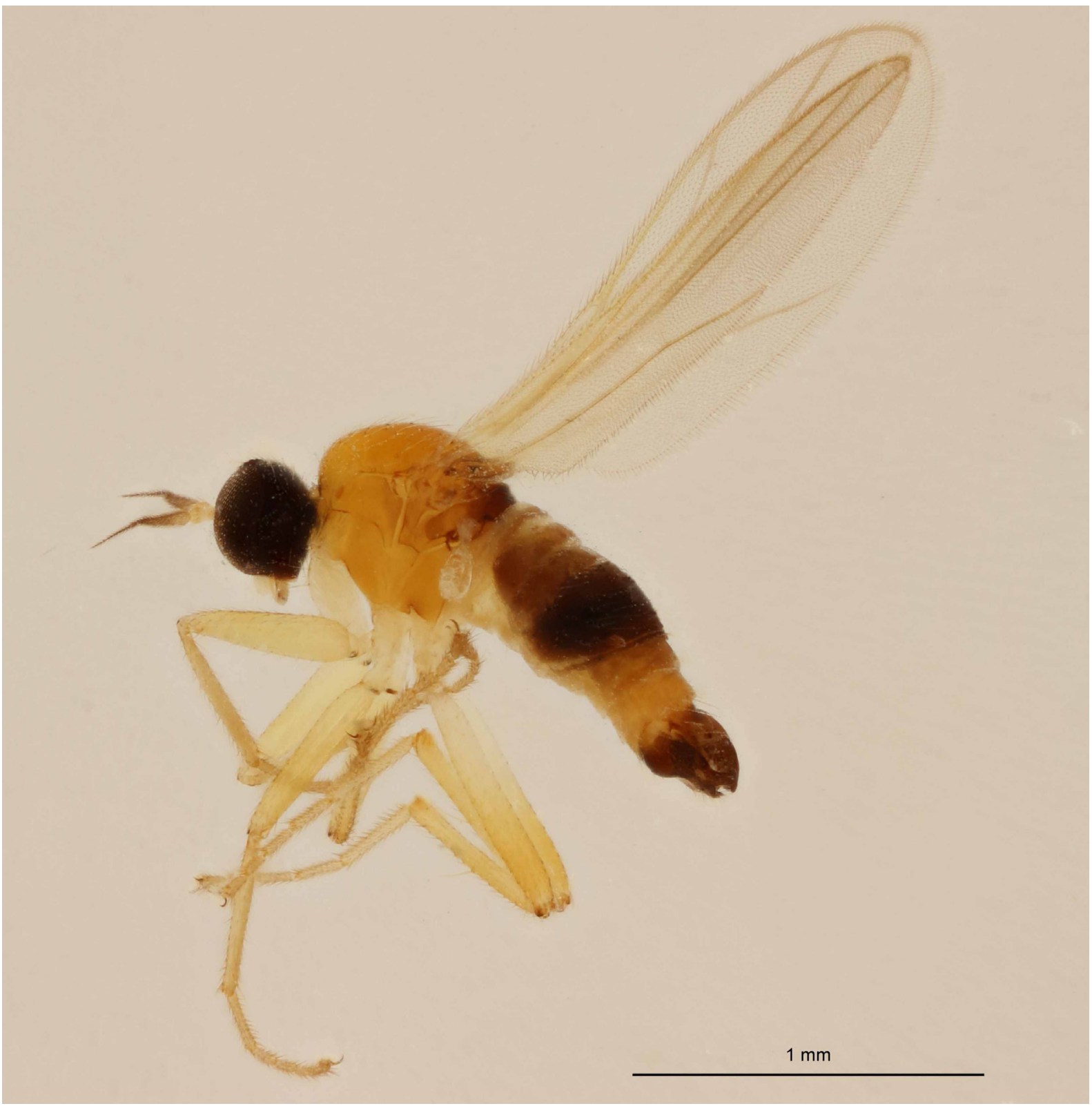

Fig. 4. Elaphropeza furcatella sp. nov., holotype, ô, habitus, RBINS (leg. C. Taylor and U. Chang; photo A. Samoh). Barcode reference JP1F. 
WING (Fig. 4). Clear. Haltere white.

LEGS. Yellow, including all tarsomeres. Fore femur with a single row of short white ventral bristles, nearly half as long as femur is wide. Mid femur with a row of ventral bristles that are longest in basal half, brownish and becoming shorter towards tip. Bristles are pale brownish in basal half. Mid tibia with a row of tiny dark spine-like ventral bristles in apical half only, row ending in a tiny black apical spine. Hind tibia with a pale anterodorsal bristle near middle.

ABDomen. Tergites 2-3 and 6-7 yellowish (not brown). Tergite 4 long, black and covered with long pale bristles that are not squamiform. Tergite 5 very narrow, with a row of indistinct pale squamiform bristles. Terminalia (Fig. 5) brown, but hypandrium yellowish at base.

TERMINALIA. Right epandrial lamella with a forked apex, right margin with four strong bristles, left fork with short bristles, right fork almost bare (Fig. 5A). Cerci apically fused, with a few strong bristles on right side (Fig. 5B). Tip of the cercus blunt (Fig.4D). Left surstylus with a wide truncate tip (Fig. 5C) with a small notch near apex (Fig. 5B, not visible on Fig. 5C). The apical border before the notch with pronounced papillae (not visible on Fig. $5 \mathrm{C}$ due to bend of the surstylus).

\section{Female}

BoDy. $1.7 \mathrm{~mm}$ long; wing $1.6 \mathrm{~mm}$ long.

Resembling male in most aspects except the mid femur with only white ventral bristles and the mid tibia without ventral spinules and lacking the tiny apical spine. Tergites $4-5$ and 8 black. Cerci short, brown. Sternite 10 not pronounced.

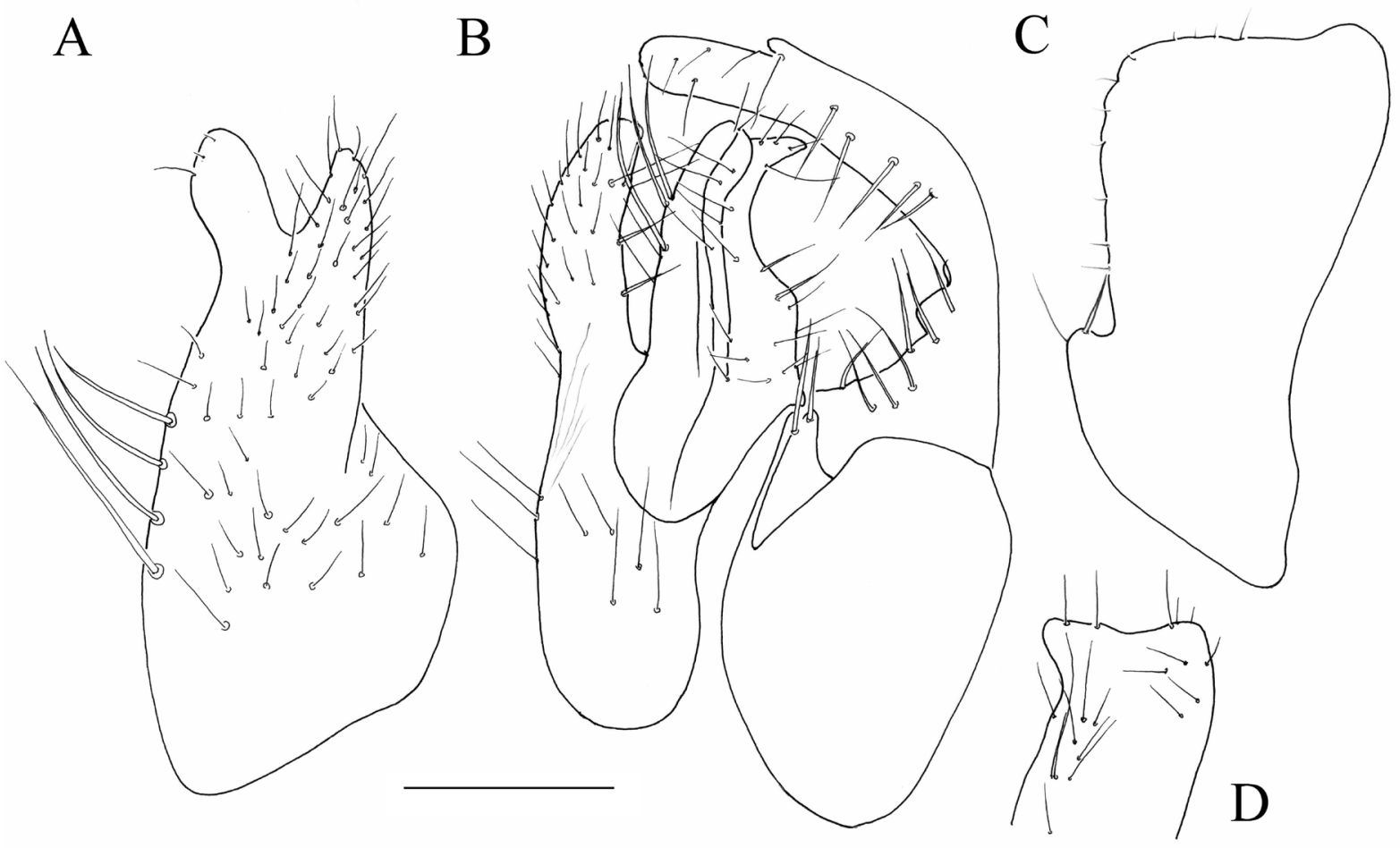

Fig. 5. Elaphropeza furcatella sp. nov., male terminalia, RBINS (leg. C. Taylor and U. Chang). A. Right epandrial lamella. B. Epandrium, dorsal view. C. Left surstylus. D. Tip of fused cerci. Scale bar: $0.1 \mathrm{~mm}$. 


\section{Remarks}

The most striking character in this species is the forked right epandrial lamella, which is quite unique in Elaphropeza. The acrostichal bristles do not reach the anterior border of the scutellum, but the presence of a small hair beside the most apical dorsocentrals might be confusing. The fore and mid tibiae and tarsi are pale yellowish, but sometimes in the female they are dusky yellow, which can lead to its being confused with E. riatanae.

Elaphropeza guenardi sp. nov.

urn:lsid:zoobank.org:act:FC83E430-3761-4BD4-B4D9-82663F8CEFE8

Figs 6-7

\section{Etymology}

The new species is dedicated to Prof. Benoit Guénard from Hong Kong University, who ran the entomological part of the survey of the mangroves of Hong Kong.

\section{Material examined}

Holotype

HONG KONG • đ'; Tung Chung (14M1); $22.28125^{\circ} \mathrm{N}, 113.92890^{\circ}$ E; C. Taylor and U. Chang leg.; 18-25 Oct. 2017; dissected and drawn (Fig. 6), with barcode reference JP1A; RBINS.

\section{Paratypes}

HONG KONG • 1 त; same collection data as for holotype; RBINS • 1 ; ; Sam A Tsuen (5AM1); $22.51534^{\circ} \mathrm{N}, 114.27121^{\circ}$ E; C. Taylor and U. Chang leg.; 11-27 Dec. 2017; RBINS.

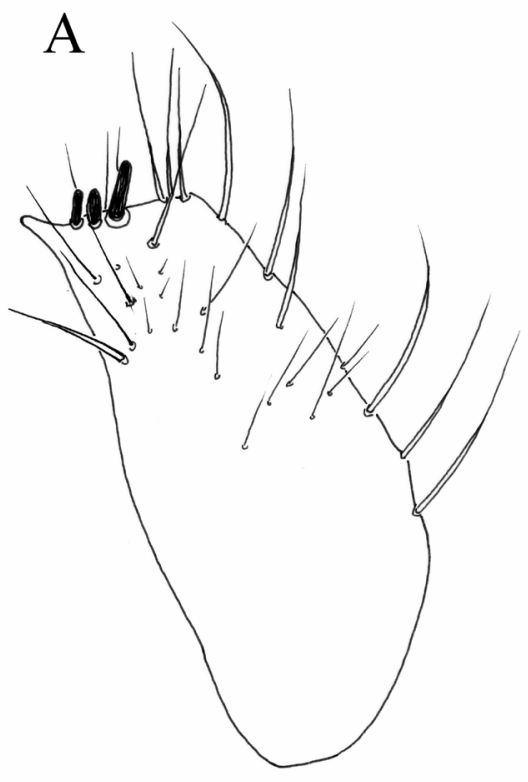

B

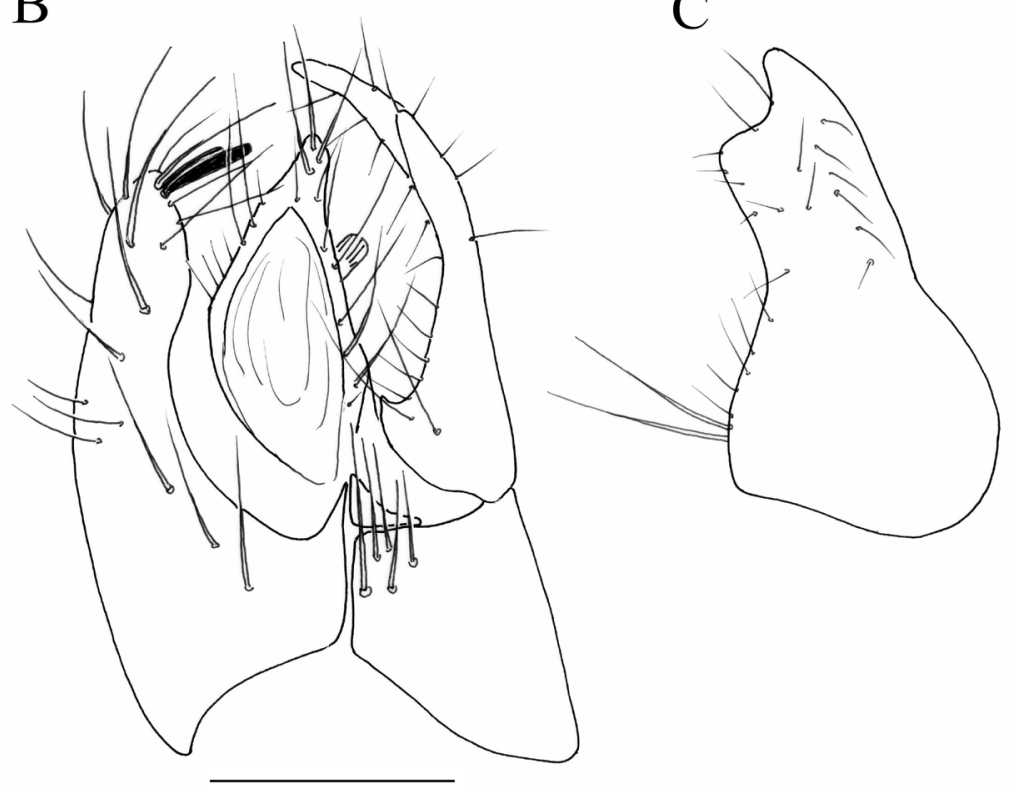

Fig. 6. Elaphropeza guenardi sp. nov., holotype, male terminalia (leg. C. Taylor and U. Chang; RBINS). A. Right epandrial lamella. B. Epandrium dorsal view. C. Left surstylus. Barcode reference JP1A. Scale bar: $0.1 \mathrm{~mm}$. 


\section{Description}

Male (Fig. 7)

BoDy. $1.2-1.5 \mathrm{~mm}$ long; wing $1.3 \mathrm{~mm}$ long.

HEAD. Occiput black, a pair of long pale ocellars. A single pair of long pale verticals (outer pair indistinct). Antenna with scape and pedicel yellow, postpedicel and stylus brown. Postpedicel $4.6 \times$ as long as wide;

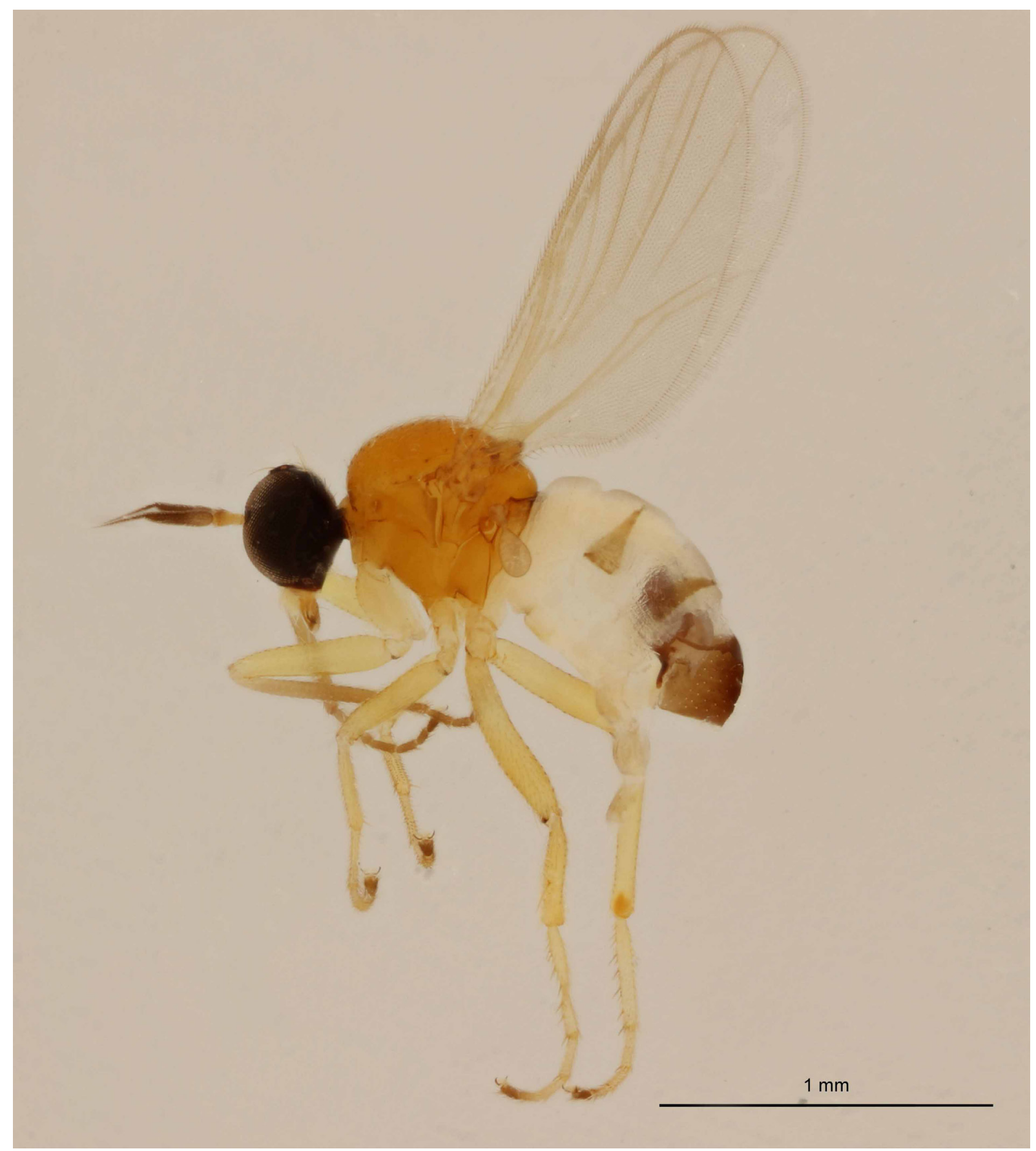

Fig. 7. Elaphropeza guenardi sp. nov., holotype, $\widehat{\jmath}$, habitus, RBINS (leg. C. Taylor and U. Chang; photo A. Samoh). 
stylus nearly as long as postpedicel $(0.8 \times)$. Palpus rounded at base, but tip pointed, yellow with pale bristles.

THORAX. Entirely orange yellow including scutellum and metanotum. Acrostichals and dorsocentrals multiserial, acrostichals reaching the border of the scutellum. A single prescutellar dorsocentral. Two notopleurals.

LeGs. Entirely yellow, except for dusky yellow fore tibia and tarsus and tarsomere 5 of all legs. Mid femur with minute fine ventral bristles only, as well as mid tibia. Hind tibia with a pale brown anterodorsal before middle, ventrally set with long white hairs, nearly as long as tibia is wide. Hind tarsomere 1 long and a little inflated, ventrally with pale brownish bristles nearly as long as the tarsomere is wide.

WING (Fig. 7). Haltere not white, but dusky.

AвDOMEn. Tergites 2-3 light brownish, tergite 4 black, densely set with pale squamiform bristles, tergite 5 black, narrow, with a row of small squamiform bristles. Tergites and sternites 7 and 8 brown.

Terminalia (Fig. 6). Cerci fused at tip, fused part short, pointed, bearing a few long setae (Fig. 6B). Right epandrial lamella with truncate tip, produced into a point on right side. Apical border bearing three black tooth-like spines (Fig. 6A). Left epandrial lamella fused with hypandrium, bearing five distinct setae (Fig. 7B). Left surstylus with a pair of long setae at base and tip with a shallow indentation (Fig. 7C).

\section{Female}

Unknown.

\section{Remarks}

The new species is closely related to E. asiophila Shamshev \& Grootaert, 2007. The differences are mainly in the male terminalia. Elaphropeza guenardi sp. nov. has three black, tooth-like spines on the apex of the right epandrial lamella, while there are only two spines in E. asiophila. The apex of the fused part of the cerci is longer in E. asiophila and the shape of the left surstylus and bristling is different. Moreover, the species differs in $4.5 \%$ of the barcode.

In the key of Shamshev \& Grootaert (2007), E. guenardi sp. nov. will key out as E. ubinensis Shamshev \& Grootaert, 2007 because the postpedicel is $4.6 \times$ as long as wide and the stylus is longer in both species than in E. asiophila. However, E. ubinensis has a brownish metanotum that is yellow in both E. guenardi sp. nov. and E. asiophila. In E. ubinensis the fused tip of the cerci is long and bears long strong spines.

\section{Elaphropeza hongkongensis sp. nov. urn:1sid:zoobank.org:act:8FDF0480-372A-4135-A1C4-FA4551C274E5}

Figs $8-9$

\section{Etymology}

The new species was the most abundant species during our study and it is therefore named after Hong Kong.

\section{Material examined}

Holotype

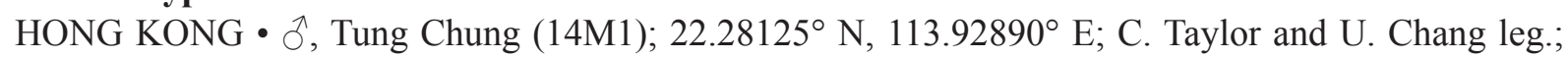
$18-25$ Oct. 2017; dissected and figured (Figs 8-9); RBINS. 


\section{Paratypes}

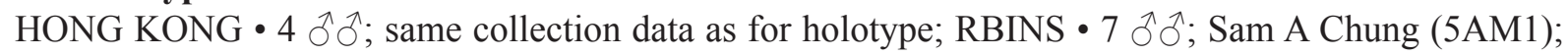
$22.50829^{\circ} \mathrm{N}, 114.27248^{\circ} \mathrm{E}$; C. Taylor and U. Chang leg.; 11 Nov. -27 Dec. 2017; all males with fore tibia ventrally brownish; RBINS $11 \mathrm{O}^{\lambda}$; Tung Chung $(14 \mathrm{M} 1) ; 22.28125^{\circ} \mathrm{N}, 113.92890^{\circ} \mathrm{E}$; C. Taylor and

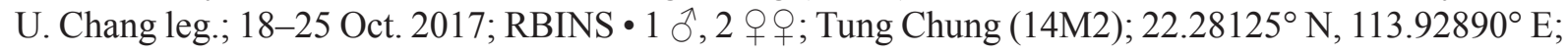
C. Taylor and U. Chang leg.; 25 Oct.-2 Nov. 2017; with barcode references: HKC0000815 +

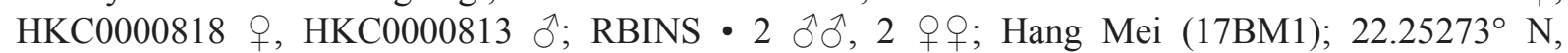
$113.86829^{\circ}$ E; C. Taylor and U. Chang leg.; 27 Oct. -9 Nov. 2017; 2 females with black sternite 10;

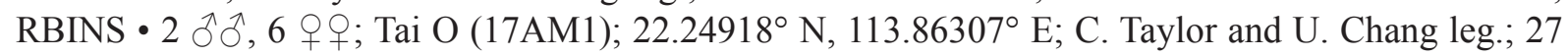
Oct.-9 Nov. 2017; RBINS • 1 गै, 1 \%; Tai O (17AM1); $22.25790^{\circ} \mathrm{N}, 113.86360^{\circ} \mathrm{E}$; C. Taylor and U. Chang leg.; 20 Oct. -2 Nov. 2017; RBINS • 1 Oे, 1 क ; Tai O (17CM1); $22.25790^{\circ} \mathrm{N}, 113.86360^{\circ} \mathrm{E}$; C. Taylor and U. Chang leg.; 20 Oct. -2 Nov. 2017; RBINS • 1 q; Wong Chuk Wan (34M1); $22.39563^{\circ} \mathrm{N}$, 114.28617 E; C. Taylor and U. Chang leg.; 5-19 Dec. 2017; barcode reference HKC0000954;

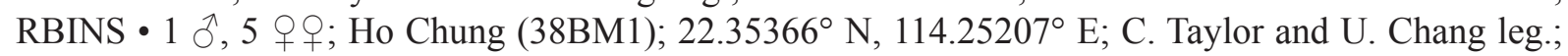
4 Dec. 2017; barcode references: HKC0000752 , HKC0000753 ㅇ, HKC0000988 , KC0000750 ㅇ, HKC0000756 §, HKC0000757 \&; RBINS.

\section{Description}

Male (Fig. 8)

BoDy. $1.7 \mathrm{~mm}$ long; wing $1.6 \mathrm{~mm}$ long (holotype).

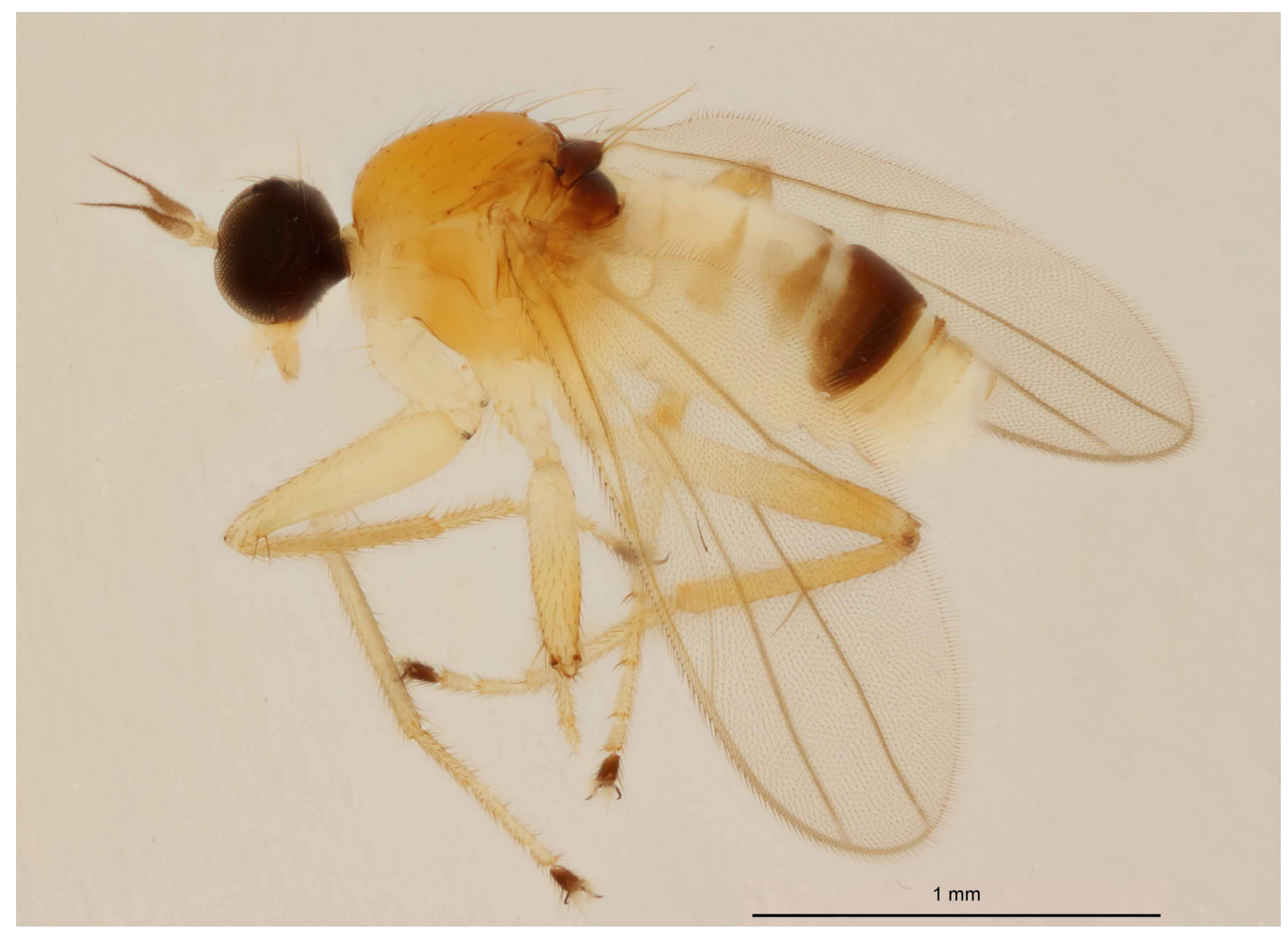

Fig. 8. Elaphropeza hongkongensis sp. nov., holotype, $\widehat{\jmath}$, habitus, RBINS (leg. C. Taylor and U. Chang; photo A. Samoh). 
HEAD. Occiput black; verticals yellow, inner vertical bristle long, outer one less than half as long as inner one. Postpedicel brownish in apical part and yellow basally, nearly $3.5 \times$ as long as wide, stylus a little longer than scape, pedicel and postpedicel together.

THORAx. Yellow, but scutellum and metanotum black; acrostichals irregular tri-serial at base, becoming biserial near middle, not reaching the border of the scutellum. Only one pale brownish long prescutellar.

LEGS. Yellow with apical tarsomere of all legs black. Fore femur with a brown preapical posteroventral bristle as long as femur is wide. Mid femur with a double row of ventral spinules, anterior row shorter than posterior row. Mid tibia ventrally with a row of short, fine, spine-like bristles ending in a subapical, brown, claw-like spine; hind tibia with one strong brown anterodorsal bristle.

Aвdomen (Fig. 8). Tergites 2-3 pale, yellowish; tergite 4 large, black with yellow hairs; tergite 5 very narrow apically, with short squamiform setae, tergites 6 and 7 yellow.

Terminalia (Fig. 9). Base of right epandrial lamella largely yellow, apical part yellow; cerci brown; dorsal half of surstylus yellowish brown, ventral half almost black. Cerci narrowly fused with right cercus small, left cercus very large (Fig. 9B). Left surstylus large, with a deep notch on dorsal border (Fig. 9C).

\section{Female}

Body. 2-2.3 mm long; wing 1.6-1.7 mm long.

Similar to male. Abdominal segment 8 enlarged.

\section{Remarks}

This species is similar to E. feminata Shamshev \& Grootaert, 2007 in most aspects. However, the notch on the dorsal side of the left surstylus is in a different position than in E. feminata. In the latter, it is a shallow notch on the apical border while in E. hongkongensis sp. nov. it is a deeper notch on the dorsal border.

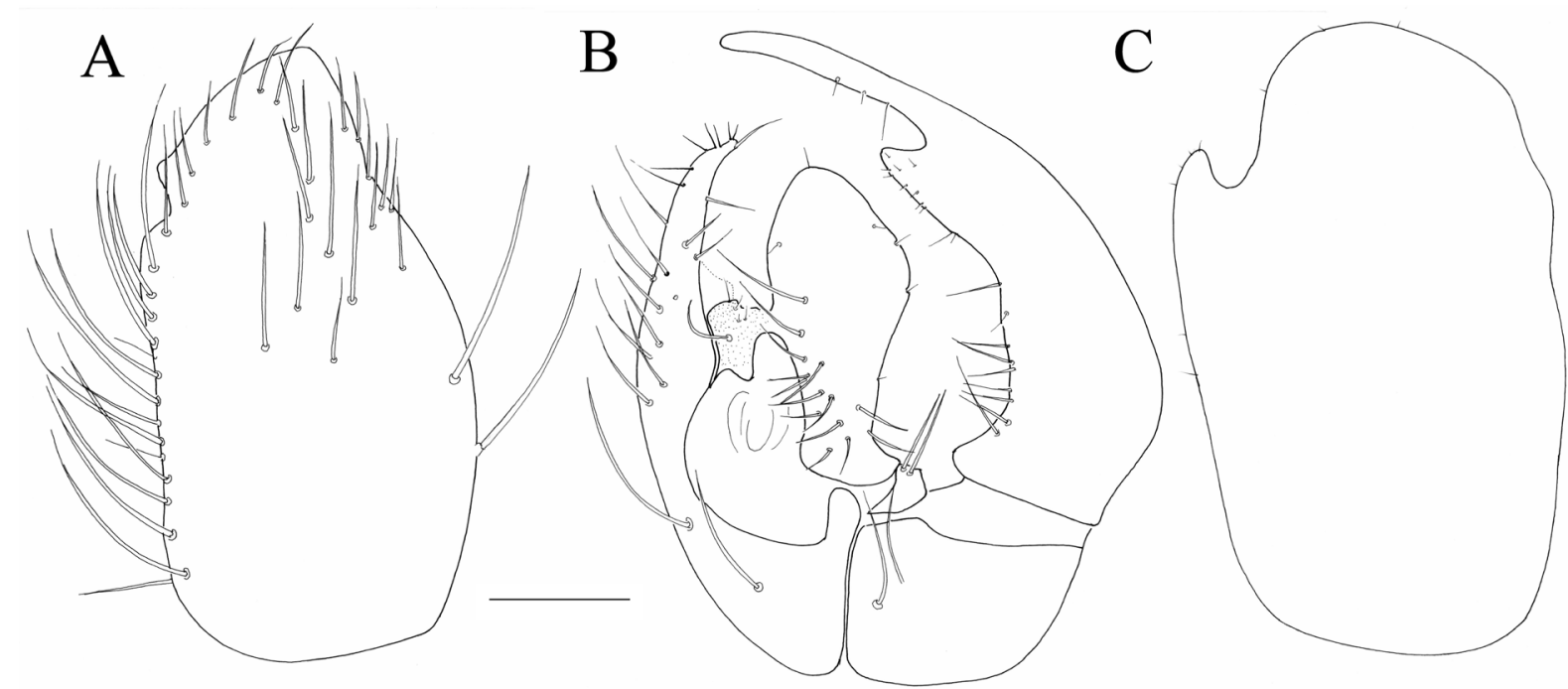

Fig. 9. Elaphropeza hongkongensis sp. nov., holotype, male terminalia, RBINS (leg. C. Taylor and U. Chang). A. Right epandrial lamella. B. Epandrium dorsal view. C. Left surstylus. Scale bar: $0.1 \mathrm{~mm}$. 
Elaphropeza hongshulin sp. nov. urn:lsid:zoobank.org:act:9128B249-0D8C-4960-9E65-CE41C89BA0DC

Figs 10-11

\section{Etymology}

The new species is named in reference to the mangroves, Hong-Shu-Lin [phonetically spelled Hóng Shù Lín], meaning 'mangrove' in Cantonese.

\section{Material examined}

\section{Holotype}

HONG KONG • ${ }^{\lambda}$; Sam A Tsuen (5AM1); 22.51534 N, $114.27121^{\circ}$ E; Malaise trap; C. Taylor and U. Chang leg.; 11-27 Dec. 2017; barcode reference JP1D; RBINS.

\section{Paratypes}

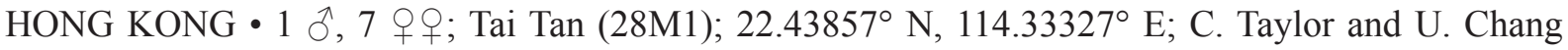
leg.; 5-19 Dec. 2017; 1 female with barcode reference JP2G; RBINS • 1 §ै; Sam A Chung (5BM1), sandy back mangrove near a stream; $22.50829^{\circ} \mathrm{N}, 114.27248^{\circ} \mathrm{E}$; C. Taylor and U. Chang leg.; 11-27 Dec. 2017; RBINS • 1 O$^{\top}$; Tai Tam (22M1); $22.24614^{\circ} \mathrm{N}, 114.22334^{\circ} \mathrm{E}$; C. Taylor and U. Chang leg.; 9-23 Oct. 2017; barcode reference HKC_0000792; RBINS • 1 đ; Tung Chung (14M2), sandy back mangrove; $22.28125^{\circ} \mathrm{N}, 113.9289^{\circ} \mathrm{E}$; C. Taylor and U. Chang leg.; 25-31 Oct. 2017; barcode reference HKC_0000819; RBINS • 1 क; Ho Chung (Nam Wai) (38AM1), muddy back mangrove; $22.35347^{\circ} \mathrm{N}$, $114.25622^{\circ}$ E; C. Taylor and U. Chang leg.; 4-18 Dec. 2017; barcode reference HKC_0000194; RBINS.

\section{Description}

Male (Fig. 10)

BoDy. 2.3-2.4 mm long; wing 2.3-2.4 mm long.

HEAD. Occiput black, postpedicel $3.0 \times$ as long as wide, stylus nearly $2.0 \times$ as long as postpedicel; scape and pedicel yellow, postpedicel pale brownish.

Thorax. Yellow, including scutellum and pleura; metanotum brown. Acrostichals biserial (tri-serial in front), lacking on prescutellar depression; dorsocentrals 1-2-serial.

LEGs. Yellow, including fore tibia; tarsomere 5 of all legs brownish black. Mid tibia with a tiny black apical spine. Hind tibia with one pale anterodorsal bristle.

WING. Clear without colour pattern. Haltere white.

AвDOMEN. Yellow except for the large black tergite 4, which bears only fine pale setae; tergite 5 brown, very narrow, with a single row of indistinct squamiform setae.

Terminalia (Fig. 11A-D). Right epandrial lamella brownish on apical half, yellow on basal half, not truncate, with ordinary apical setae and thus lacking the three black spines on the apical border as in E. malayensis (Fig. 11E), but with a single black subapical spine (Fig. 11B). Left surstylus large, brown. Cerci apically fused, yellow, with large extensions on apex (see E. malaysensis).

\section{Female}

Body. $2.4 \mathrm{~mm}$ long; wing 2.3-2.4 mm long.

Similar to male. 


\section{Remarks}

Elaphropeza hongshulin sp. nov. belongs to a complex of seven species, the others being: E. chanae Grootaert \& Shamshev, 2012, E. chanoides Grootaert \& Shamshev, 2015, E. gohae Grootaert \& Shamshev, 2012, E. lowi Grootaert \& Shamshev, 2012, E. lowioides Grootaert \& Shamshev, 2015 and E. malayensis Shamshev \& Grootaert, 2007. Externally, they are difficult to distinguish, and the male genitalia should be checked if possible. The barcodes suggest that the new species is closer related to E. lowi than to E. malayensis.

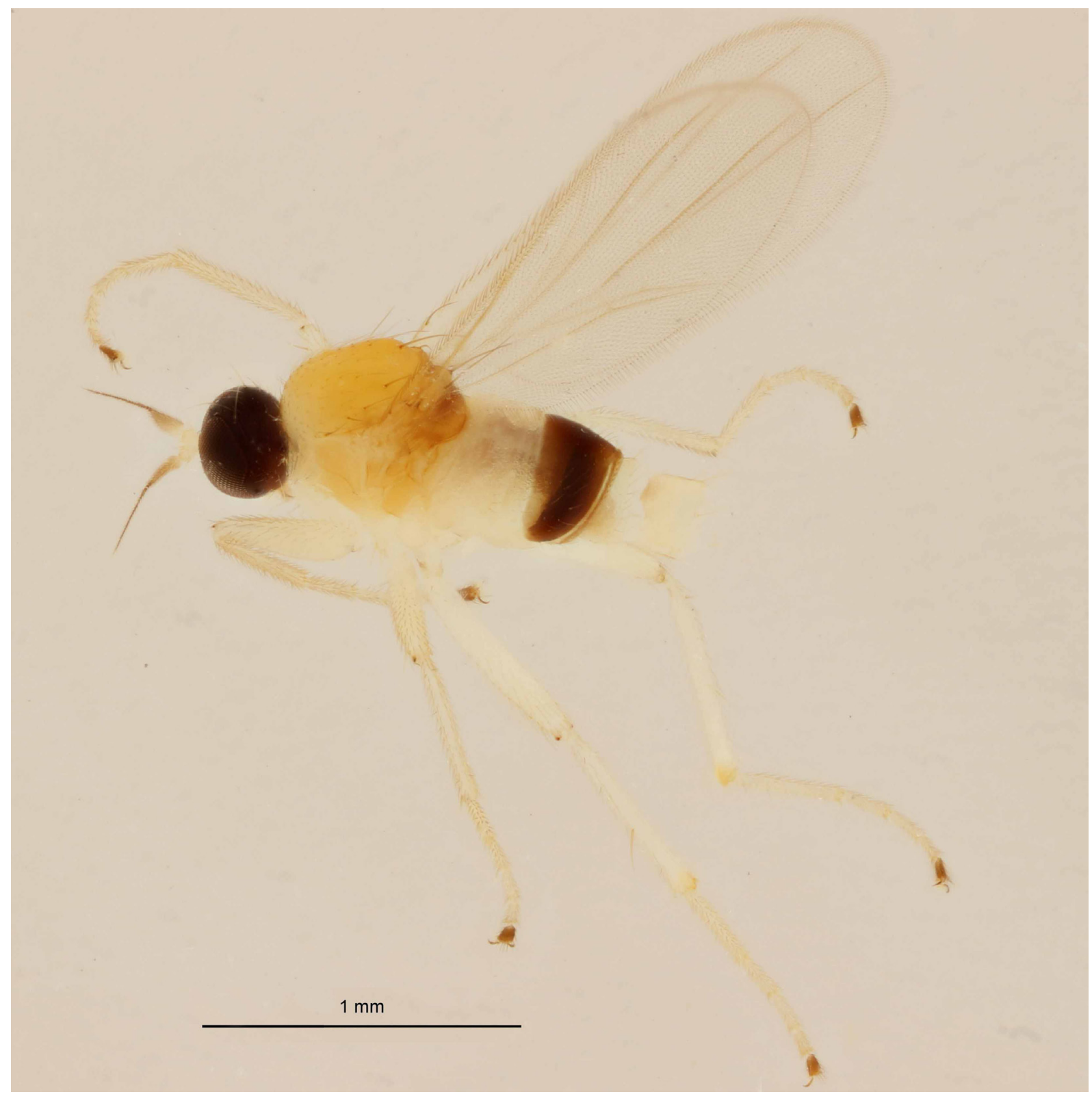

Fig. 10. Elaphropeza hongshulin sp. nov., holotype, $\hat{\partial}$, habitus, RBINS (leg. C. Taylor and U. Chang; photo A. Samoh). 


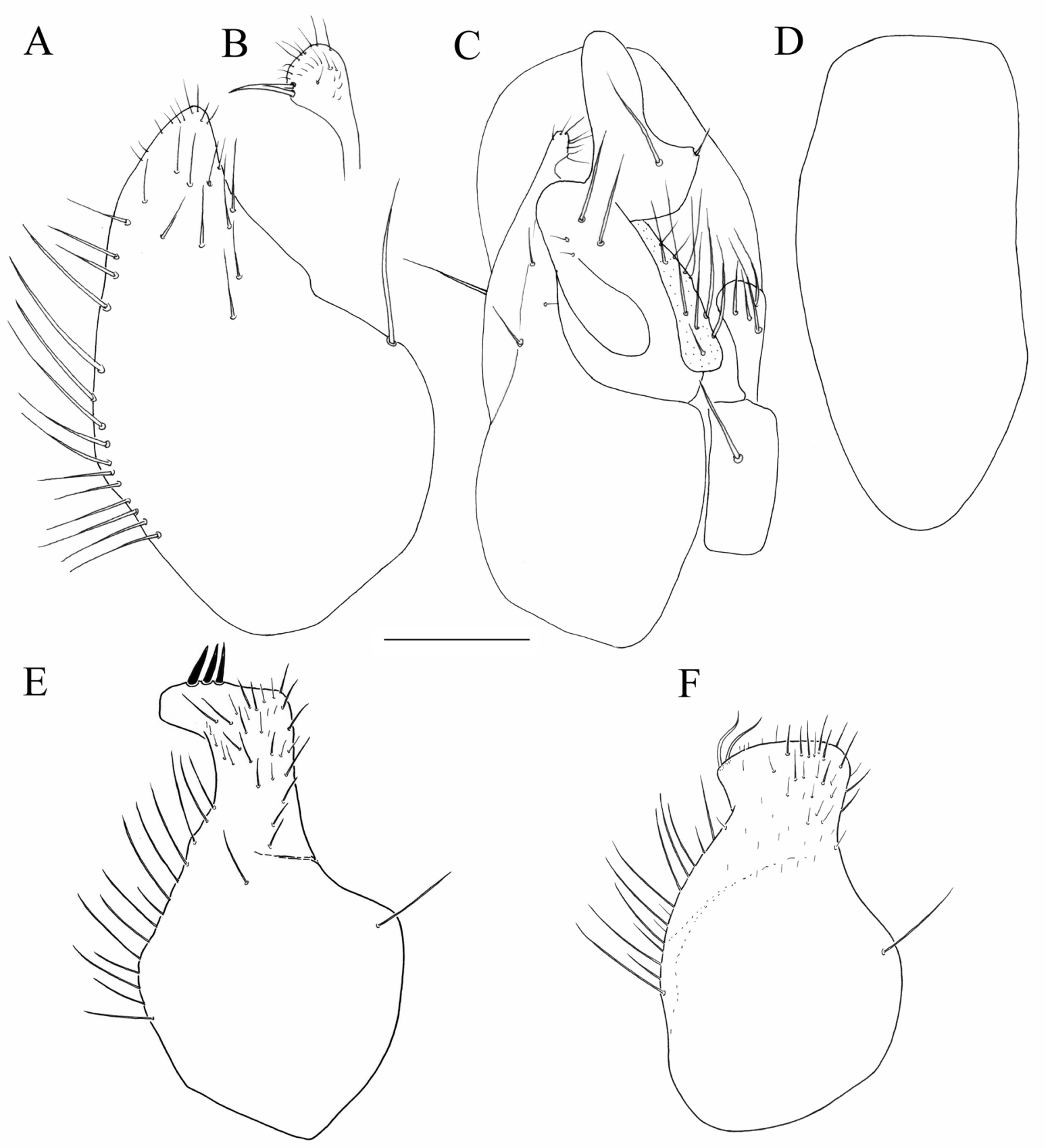

Fig. 11. A-D. Elaphropeza hongshulin sp. nov., holotype, RBINS (leg. C. Taylor and U. Chang). A. Right epandrial lamella. B. Tip of right surstylus, lateral view. C. Epandrium dorsal view. D. Left surstylus. - E. E. malayensis Shamshev \& Grootaert, 2007, right epandrial lamella (after Grootaert \& Shamshev 2012). - F. E. lowi Grootaert \& Shamshev, 2012, right epandrial lamella (after Grootaert \& Shamshev 2012). Scale bar: $0.1 \mathrm{~mm}$. 
Elaphropeza riatanae Shamshev \& Grootaert, 2007 Figs $12-13$

Elaphropeza riatanae Shamshev \& Grootaert, 2007: 88, figs 141-144; (type locality: Pulau Ubin, Chek Jawa, Singapore).

Elaphropeza riatanae - Grootaert \& Shamshev 2012: 88, new records.

\section{Material examined}

HONG KONG • 1 đं; Tai Tan (28M1); $22.43857^{\circ} \mathrm{N}, 114.33327^{\circ} \mathrm{E}$; C. Taylor and U. Chang leg.; 5-19

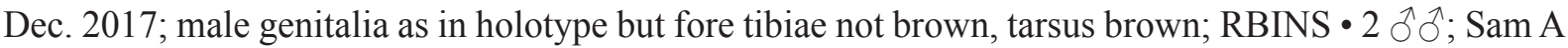
Chung (5BM1); $22.50829^{\circ} \mathrm{N}, 114.27248^{\circ} \mathrm{E}$; C. Taylor and U. Chang leg.; 11-27 Dec. 2017; 1 male has fore tibia and tarsus brown, mid tarsus as well; scutellum with only the margins brown while the second male has a black scutellum; RBINS • 3 $^{\text {}}$; Sam A Tsuen (5AM1); $22.51534^{\circ} \mathrm{N}, 114.27121^{\circ} \mathrm{E}$; C. Taylor and U. Chang leg.; 11-27 Dec. 2017; RBINS • 1 đo; Tai Tan (28M1); $22.43857^{\circ} \mathrm{N}, 114.33327^{\circ} \mathrm{E}$; C. Taylor and U. Chang leg.; 5-19 Dec. 2017; RBINS • 1 \% ; Yim Tin Tsai (45AM1); $22.37576^{\circ} \mathrm{N}, 114.30160^{\circ} \mathrm{E}$;

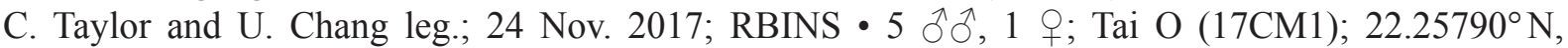

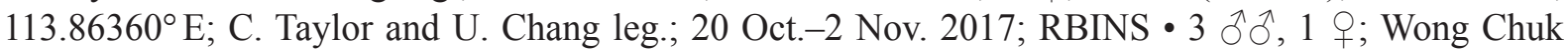
Wan (34M1); $22.39563^{\circ} \mathrm{N}, 114.28617^{\circ} \mathrm{E}$; 5-19 Dec. 2017; muddy back mangrove; barcode references:

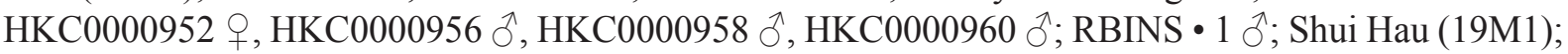

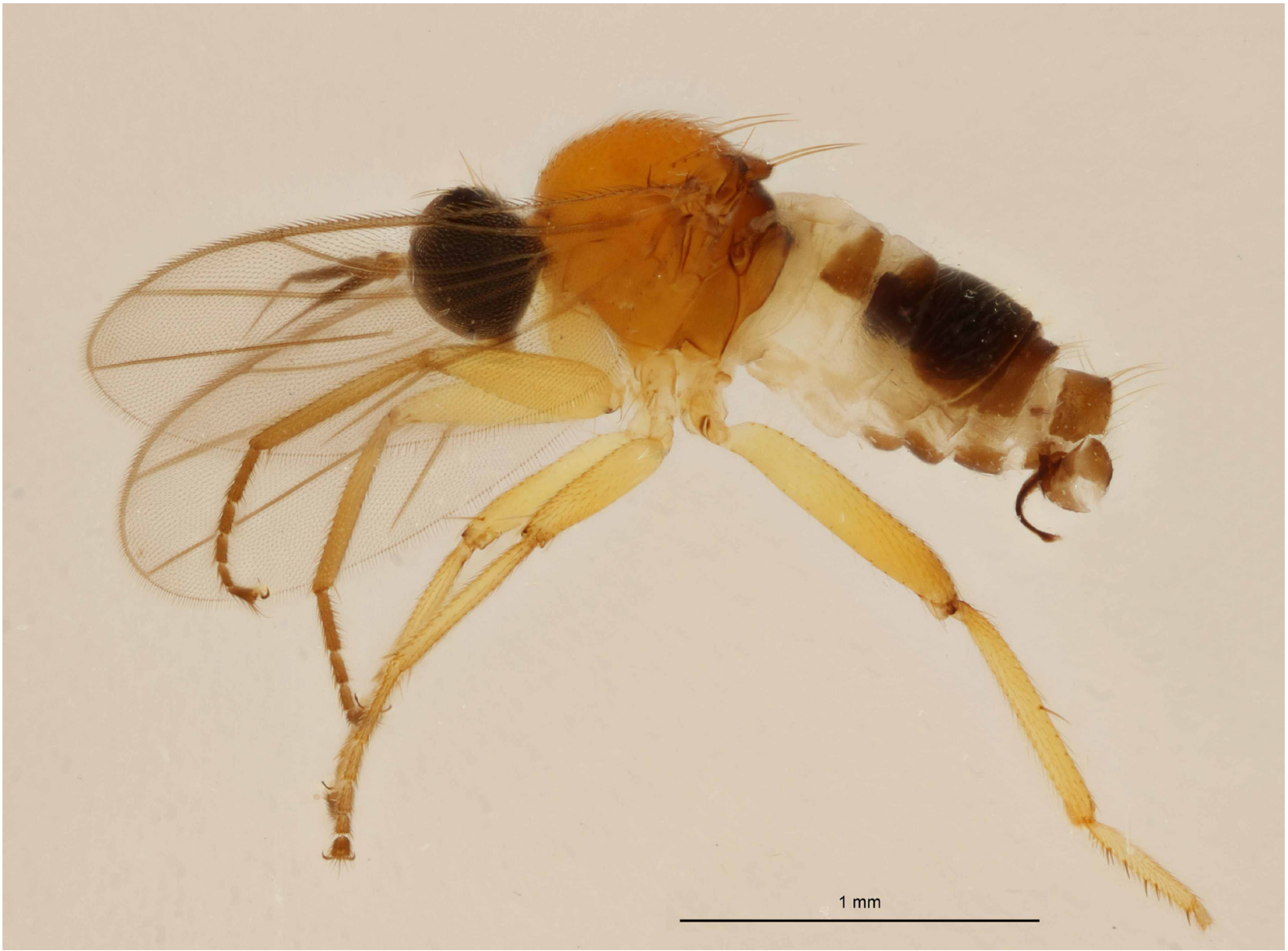

Fig. 12. Elaphropeza riatanae Shamshev \& Grootaert, 2007, §, habitus, RBINS (leg. C. Taylor and U. Chang; photo A. Samoh). 
22.21936 ${ }^{\circ}$, $113.91898^{\circ} \mathrm{E}$; $1-14$ Nov. 2017; sandy back mangrove; male terminalia figured (Fig. 13); barcode reference JP1E; RBINS $11{ }^{\lambda}$; Sam A Chung (5BM1); $22.50829^{\circ} \mathrm{N}, 114.27248^{\circ} \mathrm{E}$; C. Taylor and U. Chang leg.; 11-27 Dec. 2017; barcode reference JP1H; RBINS • 1 q; Ho Chung (38BM1); $22.35366^{\circ} \mathrm{N}, 114.25207^{\circ} \mathrm{E}$; $4-18 \mathrm{Dec} .2017$; muddy back mangrove; this female has a yellow scutellum; RBINS • 1 ; same collection data as for preceding; barcode reference HKC0000751; RBINS • 1 \% ; same collection data as for preceding; with black scutellum and the other dark body parts are also darker, fore tibia and tarsus, brownish patch on postalar callus, haltere dusky; barcode reference HKC0000747; RBINS • 1 今ं; Tai Tam (22M1); $22.24614^{\circ} \mathrm{N}, 114.22334^{\circ} \mathrm{E}$; $9-23$ Oct. 2017; sandy back mangrove; barcode reference HKC0000786; RBINS • 1 oे $^{\top}$ S Sheung Pak Nai (10M1); $22.45197^{\circ} \mathrm{N}, 113.96253^{\circ} \mathrm{E}$; 15 Nov.-1 Dec. 2017; sandy back mangrove; barcode reference HKC0001044; RBINS.

\section{Description}

Male (Fig. 12)

Body. 1.5-1.6 mm long; wing 1.4-1.5 mm long.

HEAD. Occiput black, all setae pale yellow. Scape yellow, apical half of pedicel yellowish brown, postpedicel brown, but a little paler at base; postpedicel nearly $5.0 \times$ as long as wide, stylus about as long as postpedicel. Ocellar bristles a little shorter that the verticals.

THORAX. Scutum orange yellow, scutellum brown and metanotum black; acrostichal and dorsocentral bristles multiserial, reaching the scutellum.

LEGS. Yellow with brownish pattern; fore tibia and tarsus and mid tarsus yellowish brown, in contrast to yellow femora. Mid tibia with brown ventral spinules in apical half, no apical spine. Hind tibia with one anterodorsal bristle near middle; tarsomere 1 yellow, with an irregular double row of brown spinules about as long as tarsomere is wide.

AвDOMEN. Tergites 2 and 3 brown at side, tergites 4 and 5 black, with squamiform setae, tergites 6 and 7 entirely black.
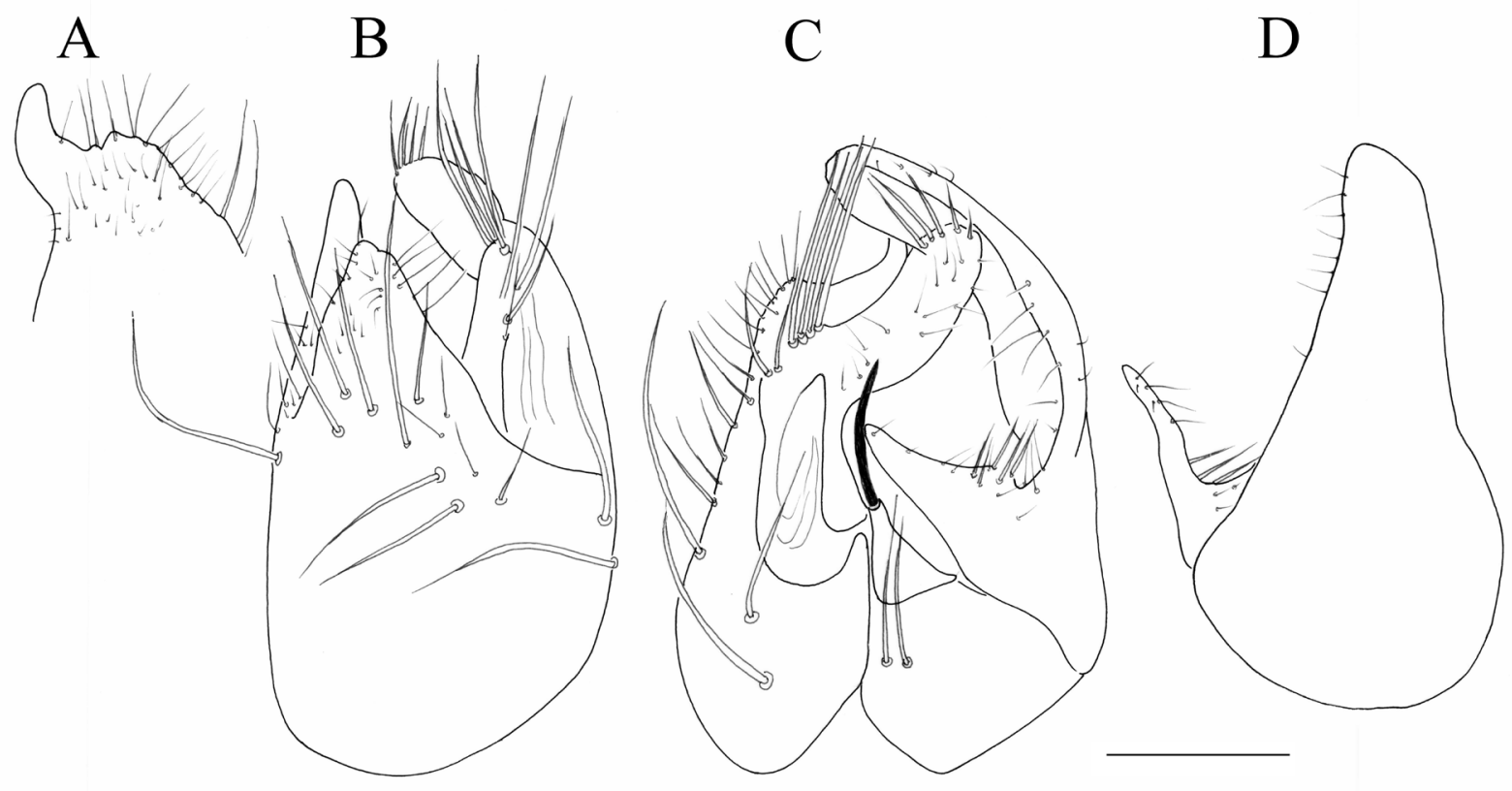

Fig. 13. Elaphropeza riatanae Shamshev \& Grootaert, 2007, male terminalia (19M1), RBINS (leg. C. Taylor and U. Chang). A. Tip of right epandrial lamella. B. Right epandrial lamella. C. Epandrium dorsal view. D. Left surstylus. Scale bar: $0.1 \mathrm{~mm}$. 
Terminalia (Fig. 13). Black. Right epandrial lamella subtriangular (Fig. 13B), tip bent and elongate to right side (Fig. 13A). Cerci fused with a row of long bristles at base of fused part, tip elongate and bent to left, with a few short bristles apically. Left epandrial lamella fused with hypandrium, bearing a papillalike protuberance bearing a strong black bristle, with two long bristles at tip of hypandrium (Fig. 13C). Left surstylus triangular in lateral view (Fig. 13D), with a long protuberance at base elongate to right side and bearing there a few short, strong bristles.

\section{Female}

Body. 1.5-1.6 mm long; wing 1.4-1.7 mm long.

Legs with identical colour pattern as in male. Ventral spinules on mid tibia less distinct than in male. Tergite 4 shorter than in male, with finer squamiform setae.

\section{Remarks}

The male terminalia of the Hong Kong specimens are similar to those of specimens from Singapore, though there are differences. The tip of the fused part of the cerci in Hong Kong males is more bent to the left and bearing at its tip a few short bristles. There are hardly any bent or short bristles on the tip of the cercus in the Singaporean specimens. The tip of the left surstylus in Hong Kong specimens seems to be more pointed than in the Singaporean specimens. Since there are no barcodes available for the Singaporean specimens to indicate that this variation is related to a large genetic distance, the specimens are considered conspecific. Elaphropeza riatanae is rare in Singapore, while very common in Hong Kong.

In the key to the Oriental species (Grootaert \& Shamshev 2012) of Elaphropeza it is stated that the scutellum is brown in this species. However, in Hong Kong there is a large variation in colour of the scutellum, from specimens with completely yellow scutellum, though generally the margin of the scutellum with the scutum is brown. Some specimens have the central area of the scutellum brown, while in others the scutellum is entirely black. The barcodes of these colour variations form a cluster of less than $1 \%$. Thus, it is considered that all form a single species. Moreover, the populations are mixed. Specimens that are overall darker, with darker fore tibia and tarsus, generally have a darker scutellum.

\section{Elaphropeza xanthocephala Bezzi, 1912}

Figs 14-15

Elaphropeza xanthocephala Bezzi, 1912: 488 (type locality: Taiwan, Takao (currently Kaohsiung)).

\section{Diagnosis}

A yellow species with a yellow occiput and a yellow scutum, but a black scutellum and metanotum. Metapleuron yellow. The tip of the hypopleuron (meron) above hind coxae with a black spot.

\section{Material examined}

HONG KONG • 1 ơ; Wong Chuk Wan (34M1); $22.39563^{\circ} \mathrm{N}, 114.28617^{\circ} \mathrm{E}$; C. Taylor and U. Chang leg.; 5-19 Dec. 2017; Malaise trap in back mangrove; barcode reference HKC0000951; RBINS.

\section{Description}

Male (Fig. 14)

HEAD. A pair of long, somewhat dark vertical setae. Antenna long. Scape yellow, pedicel dusky yellow, postpedicel entirely brown, but base yellowish brown, stylus brown. Ratio: $0.03: 0.05: 0.022: 0.325$. 
Postpedicel is $4.25 \times$ as long as wide. Stylus is $1.4 \times$ as long as postpedicel. Palpus yellow, elongate and bearing a few long setae.

THORAX. Yellow, but metanotum black and metapleuron entirely yellow.

Legs. Yellow including all coxae. Tip of hind femur dusky. All tarsomeres 5 brown. Apex of hind tibia brown. Spur pronounced.

FORE LEG. Femur lacking ventral setae. Tibia with some longer setulae.

MID LEG. Femur ventrally with a double row of spinules, multiserial at extreme base. Apical half of tibia somewhat inflated, ventrally bearing long, flattened setulae.

HIND LEG. Femur swollen in apical half, narrow in basal half; ventrally with as single row of short brown setae. Tibia with a long brown anterodorsal seta near middle. Apex with a rather strong apical rounded spur. Tarsomere 1 with a strong anteroventral seta before middle.

WING. Haltere brown.

ABdomen. Tergites 2-3 white above, brownish at sides. Tergite 4 large, with brown squamiform setae. Tergite 5 narrow, brown above, yellowish at side. Tergites 6 and 7 yellow.

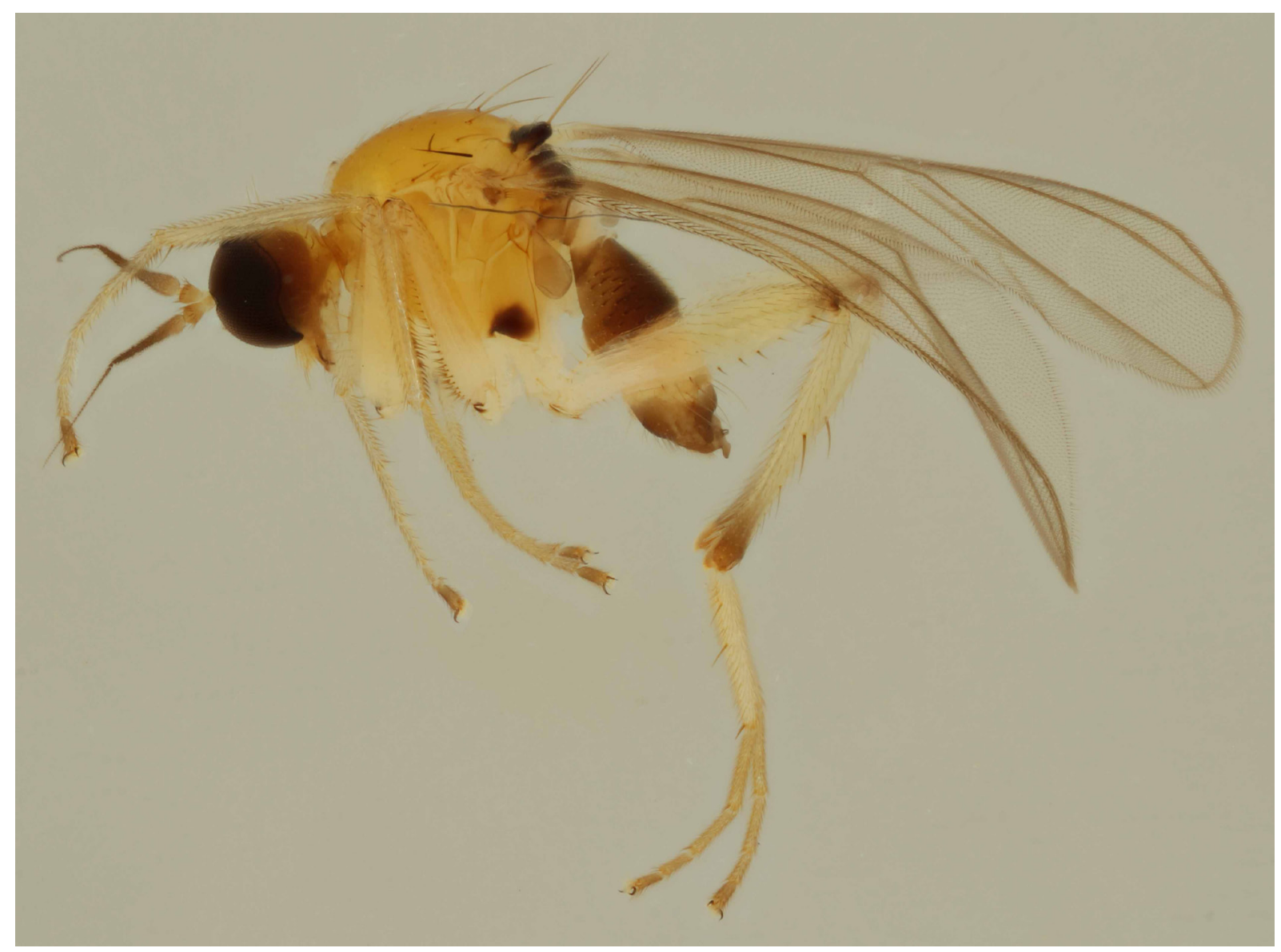

Fig. 14. Elaphropeza xanthocephala Bezzi, 1912, đ̂, habitus, RBINS (leg. C. Taylor and U. Chang; photo C. Locatelli). 
Terminalia. Pale brown (Fig. 15). Right epandrial lamella bearing two strong, flattened brown setae (Fig. 15A).

\section{Female}

Unknown.

\section{Remarks}

Elaphropeza xanthocephala is the single species with a yellow occiput occurring in Hong Kong mangroves and hence easy to recognize.

In his description, Bezzi (1912) writes that the metapleura is shining black and in the diagnosis that the metanotum is black. In our specimen the metapleura is entirely yellow and the metanotum is black. We suspect this is a lapsus or that Bezzi referred to the hypopleuron, which has an apical black spot.

Bezzi (1912) had only a single specimen from Takao which is located at the coast and it is not unlikely that this specimen was collected in the mangrove of Takao.

\section{Discussion}

The present study is based on a small sample of 105 specimens of Elaphropeza collected in 14 mangrove sites all around Hong Kong during autumn 2017 (Fig. 1). Seven different morpho-species were found that were congruent with the COI barcodes that were obtained for all seven species.

Three species were known before: Elaphropeza riatanae described from Singapore, and E. calcarifera and E. xanthocephala, both from Taiwan. The species turnover between the southern part of the South China Sea, in casu Singapore with Hong Kong in the northern part of the South China Sea, is high.

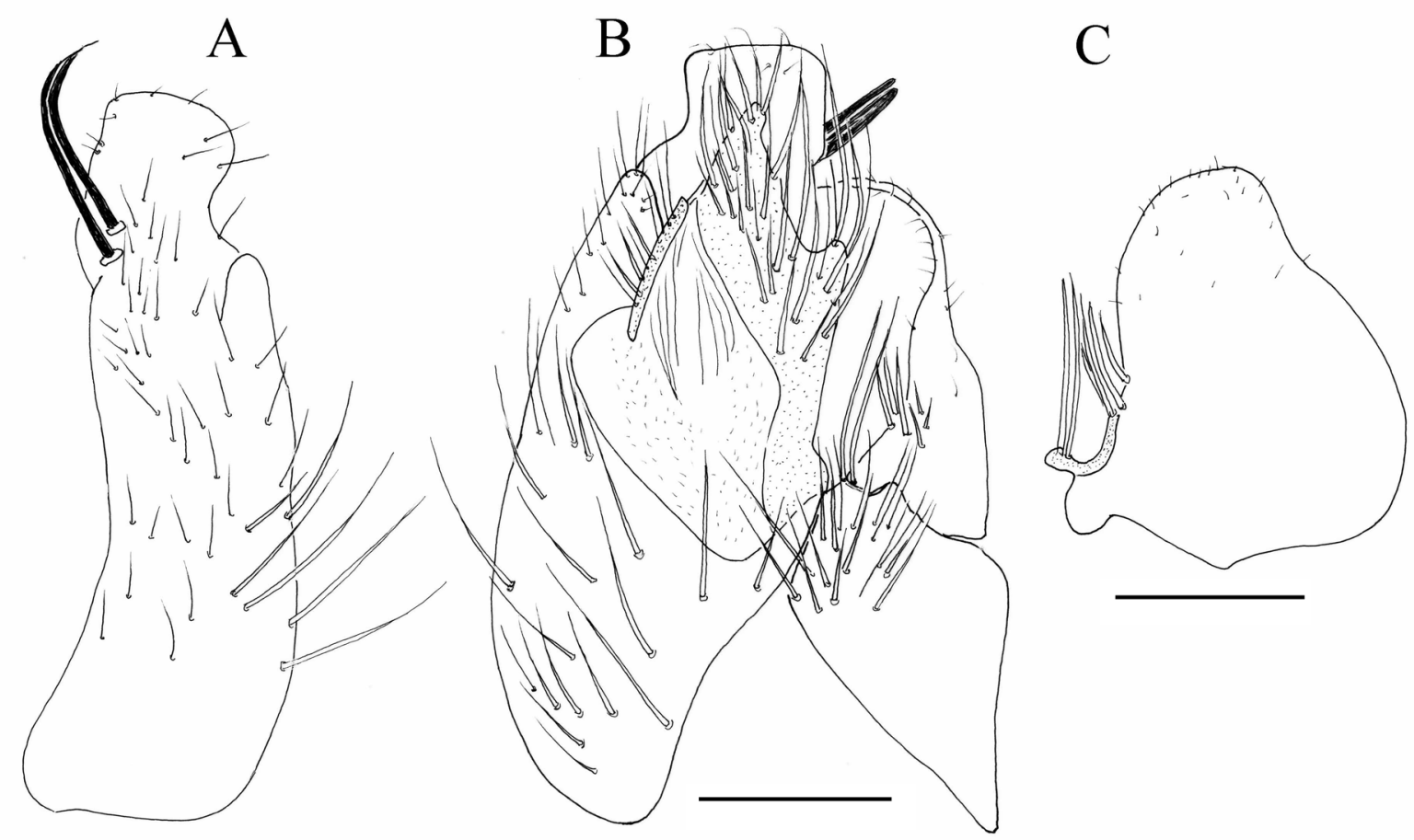

Fig. 15. Elaphropeza xanthocephala Bezzi, 1912, male terminalia, RBINS (leg. C. Taylor and U. Chang). A. Right epandrial lamella. B. Epandrium, dorsal view. C. Left surstylus. Scale bars: $0.1 \mathrm{~mm}$. 
Only E. riatanae is found in both regions. Unfortunately, no molecular data are available for E. riatanae from Singapore, so that the genetic distance with E. riatanae from Hong Kong remains unknown. This species is not common in Singapore, while it seems to be one of the dominant species in Hong Kong mangroves.

Four species are new for science. These four morpho-species are morphologically closely related to species known from Singapore. Elaphropeza furcatella sp. nov. forms a clade with E. furca Shamshev \& Grootaert, 2007 and E. riatanae Shamshev \& Grootaert, 2007; E. guenardi sp. nov. is a sibling species of E. asiophila Shamshev \& Grootaert, 2007; E. hongkongensis sp. nov. is very closely related to E. feminata Shamshev \& Grootaert, 2007 and E. hongshulin sp. nov. resembles E. lowi Grootaert \& Shamshev, 2012. This relationship is more or less reflected in the Maximum Composite Likelihood model (Fig. 16), though there is no real support for the relationship since the bootstrap values are very low. The highest bootstrap value, which is only 74, connects $E$. guenardi with E. asiophila. Since the bootstraps are very low, as can be seen in Fig. 16, it is clear that the COI barcodes cannot be used in this sample of Elaphropeza to do a phylogeny of the genus or even of the species from mangroves alone. Apparently, speciation took place a long time ago.

Over the last 2 million years, glaciations caused a sea level drop more than 50 times. The southern third of the South China Sea was dry, so that the mangroves from the south following the sea border came much closer to the mangroves in Hong Kong (Voris 2000; Grootaert 2009).

Up to now, 67 species of Elaphropeza have been reported from Singapore (Shamshev \& Grootaert 2007; Grootaert \& Shamshev 2012, 2015) and 49 species were recorded in mangrove. Ten species were found in front mangroves while 39 species occurred in back mangroves. In fact, 29 species are found exclusively in mangroves while the others also occur in terrestrial habitats such as beach forest, swamp forest or even old growth forest. Except for the black E. obscura Grootaert \& Shamshev, 2015, all other species of the front mangrove are entirely yellow. This is remarkable, since the front mangrove is the part exposed to the sun and generally hybotid species occurring in sun-exposed habitats are entirely black, while species occurring in shaded areas are yellow. Moreover, some of these yellow species from the front mangrove have also been seen foraging on rocky shores completely exposed to the sun (Grootaert unpublished).

Only seven species of Elaphropeza are found in the mangroves of Hong Kong and there may be several reasons for this low diversity. First of all, the sampling effort is low compared to that in Singapore (Grootaert \& Shamshev 2012, 2015), so that in the future the number of species might prove to be higher in Hong Kong. Secondly, Elaphropeza thrives in tropical regions and that is also why fewer species are found in Hong Kong, since it is situated at a much higher latitude and has a rather Mediterranean climate with Palaearctic relics. The hybotid Syndyas nigripes (Zetterstedt, 1842), a boreal Palaearctic species, is such an example (Grootaert, unpublished).

It is remarkable that five of the seven species found in the mangroves of Hong Kong are almost identical to species described from Singapore. They all belong to as species group with entirely yellow scutum and similar male terminalia. This indicates that a whole species group adapted to marine conditions. At least, this is the situation for Hong Kong, while more species lineages adapted to mangrove conditions in Singapore. At present, none of the Elaphropeza from mainland China, in particular nearby Guangdong, have been reported in the mangroves of Hong Kong (Yang et al. 2006).

\section{Acknowledgements}

The Hong Kong Mangroves project is supported by the Environment and Conservation Fund (ECF Project 69/2016). I heartily thank Prof. Stefano Cannicci and Prof. Benoit Guénard from Hong Kong 


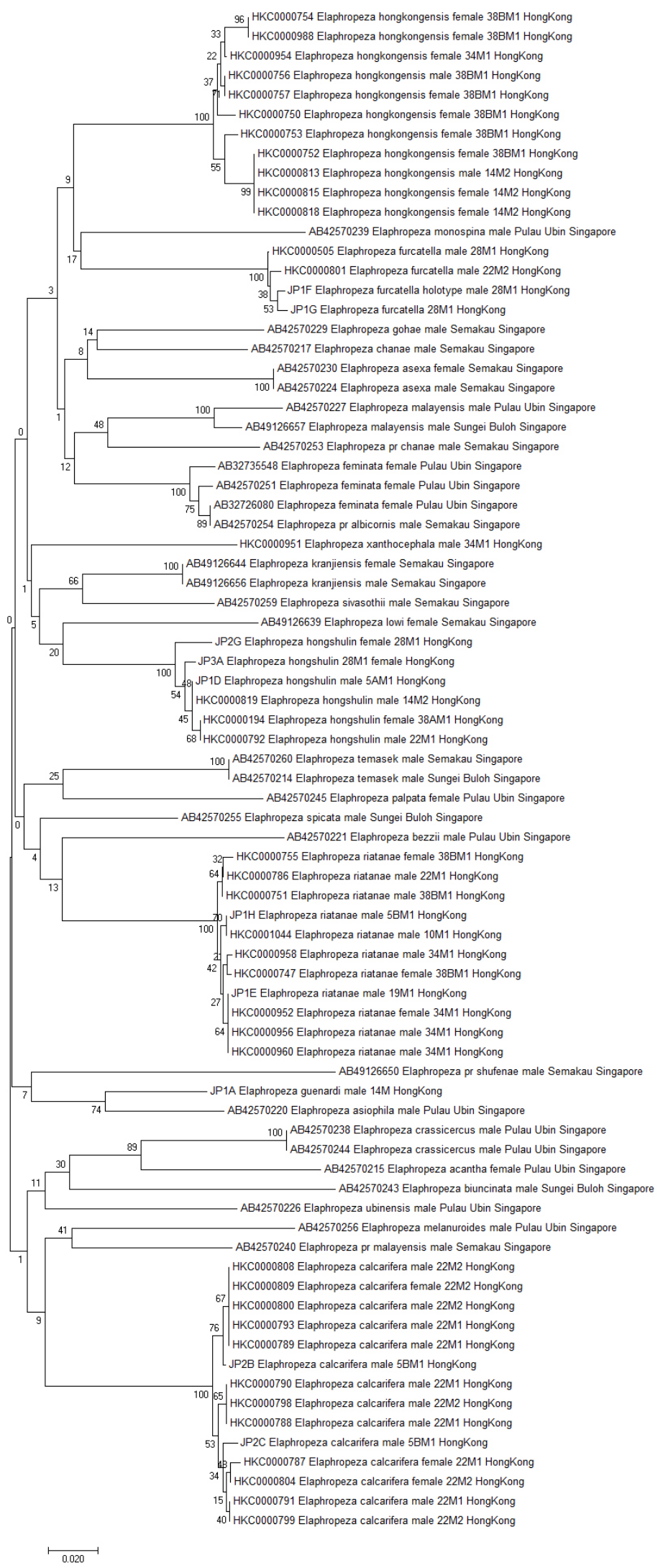

Fig. 16. Maximum Composite Likelihood model for 29 species of Elaphropeza based on COI barcodes from specimens from Singapore and Hong Kong. 
University for leading the survey of the mangroves in Hong Kong and allowing me to study the Diptera of these samples. Samples were taken by Christopher Taylor and Ukyoung Chang. Stacked photos were made by Dr Abdullah Samoh and Ms Camille Locatelli. Barcoding was done by Mr Gontran Sonet (RBINS) and Ms Jayanthi Puniamoorthy (National University of Singapore). Prof. Rudolf Meier (NUS) stimulated the molecular part of the study and provided working facilities. Dr Igor Shamshev and Dr Isabella Van de Velde gave important comments on the manuscript.

\section{References}

Bezzi M. 1904. Empididae Indo-australiani raccolti dal Signor L. Biro. Annales Historico-Naturales Musei Nationalis Hungarici 2: 320-361.

Bezzi M. 1907. Leptidae et Empididae in Insula Formosa a Clar. H. Sauter collectae. Annales Musei Nationalis Hungarici 5: 564-566.

Bezzi M. 1912. Rhagionidae et Empididae ex Insula Formosa a Clar. H. Sauter Missae. Annales Historico-Naturalies Musei Nationalis Hungarici 10: 442-495.

Brecko J., Mathys A., Dekoninck W., Leponce M., Vandenspiegel D. \& Semal P. 2014. Focus stacking: comparing commercial top-end set-ups with a semi-automatic low budget approach. A possible solution for mass digitization of type specimens. Zookeys 464: 1-23. https://doi.org/10.3897/zookeys.464.8615

Grootaert P. 2009. Chapter 7. Oriental Diptera, a challenge in diversity and taxonomy. In: Pape T., Bickel D. \& Meier R. (eds) Diptera Diversity: Status, Challenges and Tools: 197-226. Koninklijke Brill NV, Leiden.

Grootaert P. \& Shamshev I.V. 2012. The fast-running flies (Diptera, Hybotidae, Tachydromiinae) of Singapore and adjacent regions. European Journal of Taxonomy 5: 1-162.

https://doi.org/10.5852/ejt.2012.5

Grootaert P. \& Shamshev I.V. 2015. New species of fast-running flies (Diptera: Empidoidea, Hybotidae, Tachydromiinae) from mangroves in Singapore. Raffles Bulletin of Zoology 63: 583-609.

Hong Kong Observatory. 2017. Daily extract for 2017. Available from https://www.hko.gov.hk/cis/dailyExtract_e.htm?y=2017\&m=11 [accessed on 6 Nov. 2018].

Kumar S., Stecher G. \& Tamura K. 2016. MEGA7: Molecular Evolutionary Genetics Analysis version 7.0 for bigger datasets. Molecular Biology and Evolution 33: 1870-1874.

https://doi.org/10.1093/molbev/msw054

Macquart J. 1827. Insectes diptères du nord de la France. Platypezines, dolichopodes, empides, hybotides. Lille.

Meier R., Wong W., Srivathsan A. \& Foo M. 2016. \$1 DNA barcodes for reconstructing complex phenomes and finding rare species in specimen-rich samples. Cladistics 32: 100-110.

https://doi.org/10.1111/cla.12115

Melander A.L. 1928. Diptera, Fam. Empididae. In: Wytsman O. (ed.) Genera Insectorum Fasc. 185. Louis Desmet-Verteneuil, Brussels.

Meteorological Service Singapore. 2019.

Available from http://www.weather.gov.sg/climate-climate-of-singapore/ [accessed 10 Mar. 2019].

Nagy Z.T., Sonet G., Mortelmans J., Vandewynkel C. \& Grootaert P. 2013. Using DNA barcodes for assessing diversity in the family Hybotidae (Diptera, Empidoidea). In: Nagy Z.T., Backeljau T., De Meyer M. \& Jordaens K. (eds) DNA Barcoding: A Practical Tool for Fundamental and Applied Biodiversity Research. ZooKeys 365: 263-278. https://doi.org/10.3897/zookeys.365.6070

Ng P.K.L. \& Sivasothi N. 1999. A Guide to the Mangroves of Singapore (1): The Ecosystem and Plant Diversity. Singapore Science Centre, Singapore. 
Shamshev I.V. \& Grootaert P. 2007. Revision of the genus Elaphropeza Macquart (Diptera: Hybotidae) from the Oriental Region, with a special attention to the fauna of Singapore. Zootaxa 1488: 1-164. https://doi.org/10.11646/zootaxa.1488.1

Tamura K., Nei M. \& Kumar S. 2004. Prospects for inferring very large phylogenies by using the neighbor-joining method. Proceedings of the National Academy of Sciences 101 (30): 11030-11035. https://doi.org/10.1073/pnas.0404206101

Voris H.K. 2000. Maps of Pleistocene sea levels in Southeast Asia: shorelines, river systems and time durations. Journal of Biogeography 27: 1153-1167. https://doi.org/10.1046/j.1365-2699.2000.00489.x

Wang J., Zhang L. \& Yang D. 2012. Two new species and one newly recorded species of Elaphropeza Macquart from Taiwan (Diptera, Empididae, Tachydromiinae). ZooKeys 203: 15-25.

https://doi.org/10.3897/zookeys.203.3284

Wang W.Y., Srivathsan A., Foo M., Yamane S.K. \& Meier R. 2018. Sorting specimen-rich invertebrate samples with cost-effective NGS barcodes: validating a reverse workflow for specimen processing. Molecular Ecology Resources 18: 490-501. https://doi.org/10.1111/1755-0998.12751

Wong W.H., Tay Y.C., Puniamoorthy J., Balke M., Cranston P.S. \& Meier R. 2014. 'Direct PCR' optimization yields a rapid, cost-effective, nondestructive and efficient method for obtaining DNA barcodes without DNA extraction. Molecular Ecology Resources 14: 1271-1280.

https://doi.org/10.1111/1755-0998.12275

Yang D. \& Gaimari S.D. 2005. Review of the species of Elaphropeza Macquart (Diptera: Empidoidea: Tachydromiinae) from the Chinese mainland. Proceedings of the Entomological Society of Washington 107 (1): 49-54. Available from https://biodiversitylibrary.org/page/32142735 [accessed 2 Sep. 2019].

Yang D., Merz B. \& Grootaert P. 2006. Revision of Elaphropeza Macquart from Guangdong, China (Diptera, Hybotidae, Tachydromiinae). Revue suisse de Zoologie 113 (3): 569-578.

Yang D., Zhang K., Yao G. \& Zhang J. 2007. World Catalog of Empididae. China Agricultural University Press, Beijing.

Yang S., Lim R.L.F., Sheue C.-R. \& Yong J.W.H. 2011. The current status of mangrove forests in Singapore. In: Ming L.T. \& Chew H.H. (eds) Proceedings of Nature Society, Singapore's Conference on 'Nature Conservation for a Sustainable Singapore' 16 th October 2011: 99-120. Nature Society, Singapore.

Yeo D., Puniamoorthy J., Ngiam R.W.J. \& Meier R. 2018. Towards holomorphology in entomology: rapid and cost-effective adult-larva matching using NGS barcodes. Systematic Entomology 43: 678-691. https://doi.org/10.1111/syen.12296

Manuscript received: 11 May 2019

Manuscript accepted: 17 July 2019

Published on: 19 September 2019

Topic editor: Gavin Broad

Desk editor: Kristiaan Hoedemakers

Printed versions of all papers are also deposited in the libraries of the institutes that are members of the EJT consortium: Muséum national d'Histoire naturelle, Paris, France; Meise Botanic Garden, Belgium; Royal Museum for Central Africa, Tervuren, Belgium; Royal Belgian Institute of Natural Sciences, Brussels, Belgium; Natural History Museum of Denmark, Copenhagen, Denmark; Naturalis Biodiversity Center, Leiden, the Netherlands; Museo Nacional de Ciencias Naturales-CSIC, Madrid, Spain; Real Jardín Botánico de Madrid CSIC, Spain; Zoological Research Museum Alexander Koenig, Bonn, Germany; National Museum, Prague, Czech Republic. 